\title{
INTRASPECIFIC PHYLOGEOGRAPHY OF \\ THE LEAST BROOK LAMPREY (LAMPETRA AEPYPTERA)
}

\author{
A thesis presented to \\ the faculty of \\ the College of Arts and Sciences of Ohio University \\ In partial fulfillment \\ of the requirements for the degree \\ Master of Science
}

Holly R. Martin

March 2006 
This thesis entitled

\section{INTRASPECIFIC PHYLOGEOGRAPHY OF}

THE LEAST BROOK LAMPREY (LAMPETRA AEPYPTERA)

by

HOLLY R. MARTIN

has been approved for

the Department of Biological Sciences

and the College of Arts and Sciences by

Matthew M. White

Associate Professor of Biological Sciences

Benjamin M. Ogles

Interim Dean, College of Arts and Sciences 
MARTIN, HOLLY R. M.S. March 2006. Program in Molecular and Cellular Biology. Department of Biological Sciences.

Intraspecific Phylogeography of the Least Brook Lamprey (Lampetra aepyptera) (64pp.) Director of Thesis: Matthew M. White

The Least brook lamprey (LBL), Lampetra aepyptera, is a nonparasitic fish species native to the eastern United States found in small streams in the Mississippi, Mobile Basin, and Atlantic slope drainage systems. The focus of this project is to identify the geographic pattern of mitochondrial DNA variation and to recognize phylogenetically distinct clades within this species. I investigated the phylogeography of the LBL by sequencing 351 base pairs of the mitochondrial ND3 gene and approximately 650 bases of the mitochondrial control region. Samples from 21 populations throughout the LBL's distribution were sequenced. The combined ND3 and control region data sets identified 23 unique haplotypes. Ten highly differentiated clades detected correspond to drainage systems and/or geographic location. My data suggest a rapid diversification during the late Miocene and/or Pliocene, and that the LBL consists of several undescribed species. LBL distribution is likely the result of vicariance, dispersal and isolation events.

Approved:

Matthew M. White

Associate Professor of Biological Sciences 
I would like to dedicate this thesis to my husband, Breck Martin, who has provided unconditional love and support, and to my daughter, Anna, the light of my life. 


\section{Acknowledgements}

I would like to sincerely thank my advisor, Matthew M. White, for his support, patience, and guidance throughout this project. I would like to thank my committee members, Steve Reilly and Morgan Vis, and also Royal Mapes and Molly Morris from whom I received valuable support and advice. I am grateful for those who supplied samples and helped with collecting: Aaron Drake, Dave Elliott, Breck Martin, Steve Reilly of Ohio University, David Eisenhour of Morehead State University, Phil Lienesch of Western Kentucky University, Susan Adams of the USDA - Forest Service, Richard Mayden of the University of Alabama, and Wayne Starnes of North Carolina Museum of Natural

Sciences. I would also like to thank Lane Linnenkohl from the Kentucky Nature Preserves Commission, the Kentucky Department of Natural Resources, and the Tennessee Wildlife Resources Agency. Ryan Burdick, Jennifer Rybka, Maureen Peters, Katie Zipfel, Håkon Kalkvik, Josh Edwards, Natalie Dubois, and Julia Keith provided valuable lab work and support. I would also like to sincerely thank my parents, Jack and Pat Barnes, and Cathy and Dan Martin for their support. This research was supported by

Matthew M. White, the Department of Biological Sciences at Ohio University, the Program in Molecular and Cellular Biology, the Ohio University Council, and a Graduate Student Senate grant from Ohio University. I would like to express my appreciation to all who contributed to the completion of this project. 
Table of Contents

Abstract ...

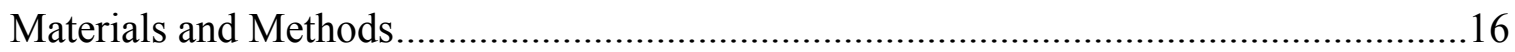

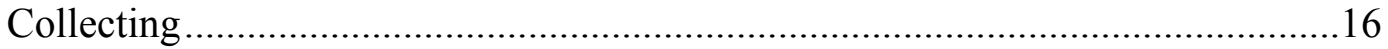

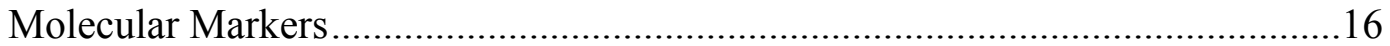

DNA Extraction and the Polymerase Chain Reaction (PCR) .............................17

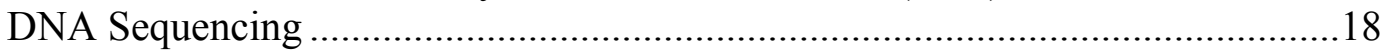

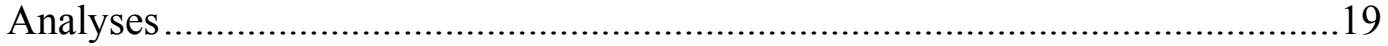

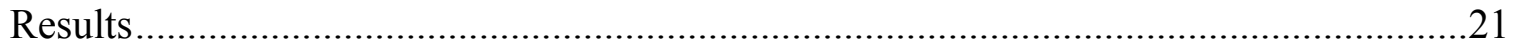

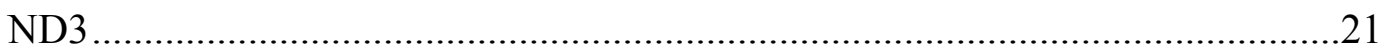

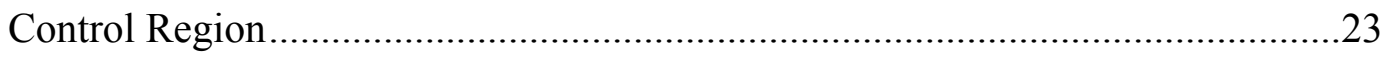

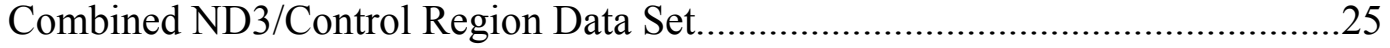

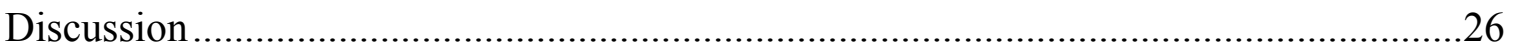

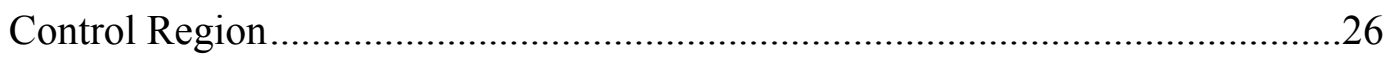

Phylogeny and Genetic Variation in Lampetra aepyptera .................................26

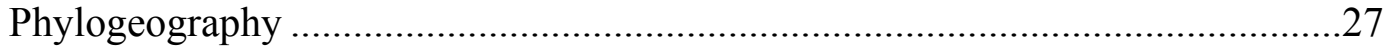

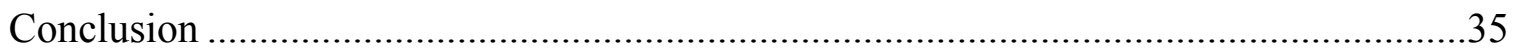

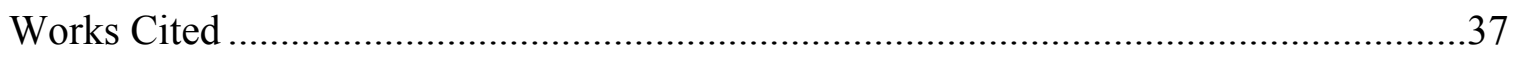

Appendix 1: Collecting Locations and Collectors ...................................................63

Appendix 2: Genbank Accession Numbers for Outgroup Sequences ............................64 


\section{List of Figures}

1. The Least Brook Lamprey, Lampetra aepyptera ..................................................44

2. Close-up of the Least Brook Lamprey, Lampetra aepyptera ...................................44

3. Distribution of the Least Brook Lamprey, Lampetra aepyptera ................................45

4. Typical Habitat of the Least Brook Lamprey, Lampetra aepyptera ...........................46

5. Map of Collecting Localities for Lampetra aepyptera Used in This Study ..............47

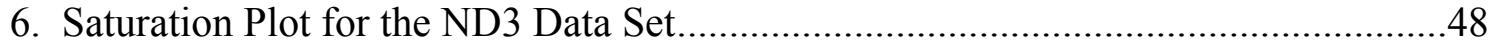

7. Minimum-spanning Network for the ND3 Data Set..........................................49

8. Neighbor-joining Tree Derived from the ND3 Sequence Data ..............................50

9. Maximum Parsimony Tree Derived from the ND3 Sequence Data ..........................51

10. Maximum Likelihood Tree Derived from the ND3 Sequence Data..........................52

11. Saturation Plot for the Control Region Data Set................................................53

12. Minimum-spanning Network for the Control Region Data Set...............................54

13. Neighbor-joining Tree Derived from the Control Region Sequence Data .................55

14. Maximum Parsimony Tree Derived from the Control Region Sequence Data ..........56

15. Maximum Likelihood Tree Derived from the Control Region Sequence Data..........57

16. Minimum-spanning Network for the ND3/control Region Data Set.........................58

17. Neighbor-joining Tree Derived from the ND3/control Region Sequence Data .........59

18. Maximum Parsimony Tree Derived from the ND3/control Region Sequence Data ..60

19. Maximum Likelihood Tree Derived from the ND3/control Region Sequence Data ..61

20. Map Depicting the Mississippi Embayment ...................................................62 


\section{Introduction}

\section{Phylogeography}

Intraspecific phylogeography provides a framework to identify the pattern of distribution of genealogical or evolutionary lineages within a species (Avise 2001). This discipline focuses on the geographic distribution of genetic diversity within and among populations of a species (Avise et al. 1987). Intraspecific phylogeography emerged from studies based on the transmission genetic features of animal mitochondrial DNA (Avise 2001) and historical biogeography, which attempts to reconstruct the history of organisms and the geologic events that have shaped their current patterns of distribution (Funk 1986; Giller et al. 1986). Population distributions are integrally tied to the past and present landscape in which they reside. By analyzing the relationship between geographic distribution and genetic variation, the history of a species' distribution may be revealed (Avise et al. 1987; Turner et al. 1996). This technique allows us to better understand how historical biogeographic factors, in addition to life histories (i.e. habitat preferences, dispersal capabilities, etc.), affect populations and their present distribution (Avise et al. 1987; Avise 2001). Understanding intraspecific phylogeographic relationships may provide insight into mechanisms of cladogenesis and speciation (Hardy

et al. 2002). Intraspecific phylogeography has been used to elucidate the history and relationships of many species (i.e. Ruedi et al. 1997; Starkey et al. 2003; Johnson 2005; Kuchta and Tan 2005; Ruokonen et al. 2005).

Most species encompass populations with different geographical distributions that may have little or no contact for long periods of time (Avise et al. 1987; Avise 2001). 
Thus, many species exhibit genetic population structuring due to the presence of barriers to gene flow and concurrent departure from random mating (Avise and Felley 1978; Avise et al. 1987). The degree of genetic structuring often reflects the extent of gene flow among populations. Limited genetic structuring often indicates the absence of barriers to gene flow between populations (Avise et al. 1987; Chenoweth and Hughes 1997).

Three aspects should be evident in genetic structuring resulting from the lack of gene flow (Avise et al. 1987). First, as time since separation increases, genetic differentiation among isolated populations also increases. Second, populations or species with a common history will exhibit congruence in their patterns of differentiation. Finally, geographic barriers to gene flow may be reflected in well-differentiated clades within species. Well-differentiated clades are groups of populations that exhibit considerable genetic differentiation from other groups. Barriers created as a result of continental separations, glaciations, and drainage rearrangements have greatly affected patterns of population differentiation and speciation (Briggs 1986; Avise and Walker 1998, Avise et al. 1998).

\section{Phylogeography and Eastern North American Fishes}

Freshwater fishes provide an excellent opportunity to study the effects of geologic events and life histories on current population distributions. Most freshwater fish populations are separated into different drainage systems. Dispersal capabilities, habitat, and life history often determine the level of phylogenetic structuring. Many freshwater organisms experience little gene flow (Johnson 2005) and often exhibit significant 
phylogenetic structuring (Avise 2001; Hardy et al. 2002). The Missouri saddled darter, Etheostoma tetrazonum, endemic to the Ozark Plateau of Missouri, consists of two, wellsupported monophyletic clades: one in the tributaries of the Missouri River and one in the Meramec River, a tributary of the Mississippi River (Switzer and Wood 2002). Although these rivers are geographically close, little gene flow has occurred between them, resulting in highly differentiated clades and likely different species. Three highly differentiated populations of the Ashy darter, Etheostoma cinereum, were identified in the Cumberland River, the Duck River (lower Tennessee River), and upper Tennessee River (Powers et al. 2004). Populations of the Crystal darter, Crystallaria asprella, also exhibit considerable divergence among populations in different drainages (Wood and Raley 2000).

Freshwater fishes are dependent on the flow of streams and rivers. When events occur that disrupt drainage systems, habitat and dispersal of fishes may be affected (Strange and Burr 1997). Stream capture between drainages is a major dispersal mode for freshwater fishes (Gilbert 1976; Burr and Page 1986) and has been used to explain the presence of fishes in some drainages (i.e. Howard 1993; Strange 1998). Geologic events, such as glaciation, uplift, faulting, or folding, can also result in drainage pattern rearrangements (Hocutt 1979) and may consequently shape the distribution of fish populations (Avise et al. 1998; Briggs 1986; Mayden 1988).

The Pleistocene glacial period involved four separate advances and recessions of glaciers into the United States (Nebraskan, Kansan, Illinoian, and Wisconsinan) separated by three fluvial periods (Aftonian, Yarmouth, and Sangamon) (Hocutt et al. 1986). The 
distribution and evolution of North American fishes were greatly affected by these incursions (Burr and Warren 1986; Hocutt et al. 1986; Robison 1986). Drainage systems present in the pre-Pleistocene eastern United States were markedly different than presentday drainages. Glacial advances resulted in the reorganization of some of the major drainage systems (Hocutt et al. 1986; Robison 1986; Thornbury 1965).

The Central Highlands were once a continuous topographic feature in the eastern United States (Robison 1986; Mayden 1988). Pleistocene glaciations dramatically changed the contiguous highland region into disjunct regions, the Eastern Highlands and the Interior Highlands containing the Ouachita and Ozark mountains west of the Mississippi River (Mayden 1988). Regions including Ohio, Illinois, and Indiana (Central Lowlands) were buried under glacial till, and a region that once contained high gradient streams became a region with low gradient streams characteristic of lowland topography (Mayden 1988; Strange and Burr 1997). Prior to glaciation, many species were most likely continuously distributed throughout the Highland region (Burr and Warren 1986). The glaciers split the ichthyofauna into populations inhabiting Eastern and Interior Highland refugia (Burr and Warren 1986).

Our understanding of patterns of distribution of North American fishes is based on hypotheses of vicariance and dispersal (Mayden 1988; Strange and Burr 1997; Near et al. 2001; Berendzen et al. 2003). Vicariance occurs when a species' range splits by some barrier to gene flow and the subsequent differentiation among populations (Mayden 1988). Speciation by dispersal, on the other hand, is the migration and isolation of individuals that diversify from an ancestral population. 
The pre-Pleistocene vicariance hypothesis was proposed as a possible explanation for faunal similarity between the Central Highland regions (Mayden 1988). This hypothesis suggests that the distribution of highland ichthyofauna was continuous prior to the Pleistocene (Mayden 1988). Fragmentation of highland fauna resulted from Pleistocene glaciations that altered drainage systems and divided the highland region (Mayden 1988; Berendzen et al. 2003). Present distributions of highland fishes should reflect pre-glacial drainage patterns rather than current drainage patterns (Mayden 1988).

Phylogeographic patterns in mitochondrial DNA (mtDNA) and geologic evidence have been used to suggest historical drainage patterns and fish distributions (Avise 2001). Strange and Burr (1997) examined the phylogeography of five species groups of Central Highlands fishes. Three of the five species groups were characterized by pre-Pleistocene vicariance events. The remaining two groups suggested recent dispersal events between Eastern and Interior Highlands. The present distribution of Percina evides was not only suggestive of dispersal during or following the Pleistocene, but also appeared to support the pre-Pleistocene vicariance hypothesis (Near et al. 2001). Berendzen et al. (2003) found that relationships of haplotypes within Hypentelium nigricans suggested both dispersal and vicariance events to best explain current distribution. The distribution of many fishes in eastern North America may be best explained by a combination of vicariance, dispersal, and peripheral isolation events (Mayden 1988; Strange and Burr 1997; Near et al. 2001; Berendzen et al. 2003). 
Lampetra aepyptera

The Least brook lamprey (Lampetra aepyptera: Petromyzontidae; Abbott 1860) (Figures 1-2) is a nonparasitic, freshwater fish species widely distributed in the major drainage systems of the eastern United States (Figure 3). It is distributed throughout the Mississippi, Mobile Basin, and Atlantic coast drainage systems. L. aepyptera would not likely be considered a member of the Central Highlands fauna (Mayden 1988) because it is found in both lowland and upland regions where appropriate habitat is present.

Lampetra aepyptera prefers small to medium sized streams with silty/sandy

substrates (Figure 4). It usually exhibits a three (Seversmith 1953) to six year (Walsh and Burr 1981) life cycle. Differences in the length of life cycle may be attributed to variations in physical and biological conditions evident in different river systems (Rohde et al. 1976). Ammocoetes burrow into the substrate and filter feed on microorganisms and detritus (Stilwell 1974) for three to five years (Hubbs 1971; Rohde et al. 1976; Seversmith 1953; Walsh and Burr 1981). Metamorphosis usually occurs in the late fall (the exact timing of metamorphosis appears to be location and population dependent) at which time lampreys cease feeding and prepare for spawning in the early spring. Metamorphosis is dependent on environmental, metabolic, and hormonal cues (Youson 1997). Spawning sites are selected near or in riffle areas where the substrate consists of small gravel (Seversmith 1953). Individuals sampled in Maryland were found in all stages in a mile-long stretch of stream, suggesting that individuals do not have to leave or migrate during their lifetime (Seversmith 1953). Adult Least brook lampreys live for approximately six months and die following spawning. 
Lampetra aepyptera possesses the most reduced dentition of any species in Petromyzontidae (Bailey 1980). Since dentition is often used in establishing species limits and the relationships among lamprey species, the absence of dental characters has created problems about its placement in the genus Lampetra. It was relegated to the monotypic genus Okkelbergia (Jordan et al. 1930) but subsequently returned to Lampetra (Vladykov and Kott, 1976). Vladykov et al. (1975) concluded that the lampreys from the Mobile Basin drainages constituted a new species, Lethenteron meridionale. However, due to a lack of diagnostic characters, this taxon was synonymized with Lampetra aepyptera (Bailey 1980).

There does appear to be some variation (i.e. dentition, ontogeny, length of life cycle; morphology) in L. aepyptera populations (Seversmith 1953; Walsh and Burr 1981; Page and Burr 1991). Populations from the Atlantic slope lack a black stripe through the eye, gold stripe on the dorsal fin, and dark-tipped caudal fin (Page and Burr 1991). Seversmith (1953) suggested only a provisional classification of Maryland populations as L. aepyptera. Populations from the Obion River in Tennessee and Kentucky appear to be neotenic (Walsh and Burr 1981). Specimens collected appeared to be sexually mature but did not display the usual nuptial characters associated with L. aepyptera (enlarged eye, dark pigmentation, enlarged dorsal fin, and pseudo-anal fin). Ammocoetes may not be accumulating sufficient lipid stores to fully metamorphose (Walsh and Burr 1981). An allozyme study of this and other L. aepyptera populations (Drake 2002) suggested highly significant differentiation between the neotenic population and other lamprey populations. 
Objectives

I present a phylogeographic study of L. aepyptera based on sequence variation of the mitochondrial NADH dehydrogenase subunit 3 (ND3) gene and a portion of the mitochondrial control region. My goals are to identify the geographic pattern of mitochondrial DNA variation and to recognize phylogenetically distinct clades within this species. I consider the impact of dispersal and vicariance in the present distribution of L. aepyptera. I predict that L. aepyptera will exhibit distinct phylogroups based on current and past drainage patterns. Because dispersal between drainages appears to be low (Seversmith 1953), I predict gene flow will also be low and population structuring will be significant. This research may also identify the presence of undescribed species. 


\section{Materials and Methods}

\section{Collecting}

Individuals from 21 populations were collected from streams throughout the distribution of Lampetra aepyptera using seines, dipnets, and a backpack electroshocker (Figure 5, Appendix 1). Three populations from the Atlantic slope, one population from the Mobile Basin and seventeen populations from the Mississippi drainage system were collected. Specimens were preserved in 95\% ethanol.

\section{Molecular Markers}

The NADH dehydrogenase subunit 3 (ND3) gene and a portion of the control region were amplified for this study. Docker et al. (1999) used both the cytochrome $b$ (cyt $b$ ) and ND3 genes in a phylogenetic study of the genus Lampetra. Their data suggest the mutation rate of ND3 is 1.35 times faster than that of cyt $b$, thus making ND3 an appropriate marker for an intraspecific phylogeographic study of a Lampetra species.

Variation in the control region can be seen as substitutions, indels, and variable numbers of tandemly repeated sequences (Faber and Stepien 1998). Because this region generally mutates at a faster rate than other mitochondrial regions, it can provide useful information for groups that have been separated for only a short period of time (Faber and Stepien 1997). Variation within the control region has been effective in phylogenetic analyses (Faber and Stepien 1998; Froufe et al. 2003; Froufe et al. 2005, Salzburger et al. 2003; Stefanni and Thorley 2003). Studies based on the sea lamprey (Petromyzon marinus; Lee and Kocher 1995) and the European lamprey (Lampetra fluviatilis; Delarbre et al. 2000) suggest that lamprey control regions contain two separate regions, 
as opposed to a continuous control region sequence seen in most vertebrates (Stepien and Faber 1998). The first segment of the lamprey control region is thought to contain most of the regulatory sequences for replication (Lee and Kocher 1995). Control region sequence I refers to this first section of the control region. DNA Extraction and the Polymerase Chain Reaction (PCR)

Total genomic DNA was extracted using a DNeasy Kit (Quiagen, Inc.). The ND3 gene and a portion of the control region were amplified by the polymerase chain reaction (PCR). Each reaction contained $1 \mathrm{X}$ Bioline $\mathrm{NH}_{4}$ reaction buffer, $0.2 \mathrm{mM}$ each dNTP, 3.0 $\mathrm{mM} \mathrm{MgCl} 2,0.5 \mu \mathrm{M}$ each of heavy- and light-strand primers, 2.5 units of Taq polymerase, and $2.0 \mu \mathrm{L}$ of template DNA bringing the total reaction to $20 \mu$. Amplification took place in an MJ Research PTC-25 thermal cycler. The ND3 heavy-strand primer [ATG CGG ATC CTT TTG AGC CGA AAT CA] and the ND3 light-strand primer [ACG TGA ATT CTA TAG TTG GGT TCC AAC CA] (Docker et al. 1999) were used for all reactions. The PCR reaction for ND3 was 25 cycles of $94^{\circ} \mathrm{C}$ for 30 seconds, $50^{\circ} \mathrm{C}$ for 30 seconds, and $72^{\circ} \mathrm{C}$ for 30 seconds.

Control region sequence I was amplified using primers based on the Lampetra fluviatilis sequence (Genbank accession no. NC001131). The control region heavystrand primer LACR3F [TAC CCC CAT GGT ACA AAA TAA CA] and the control region light-strand primer LACR3R [CTG GTT TAC AAG ACC AGT GCT TT] were used for all reactions. The PCR reaction consisted of an initial denaturation step at $94^{\circ} \mathrm{C}$ for 3 minutes, followed by 30 cycles of $94^{\circ} \mathrm{C}$ for 30 seconds, $64^{\circ} \mathrm{C}$ for 30 seconds, and $72^{\circ} \mathrm{C}$ for 30 seconds. Amplification products were verified on a $0.8 \%$ agarose gel. The 
ND3 gene is approximately 351 base pairs, and the portion of the control region amplified is approximately 650 base pairs, depending on the number of tandem repeats present.

DNA Sequencing

Following product verification, PCR products were purified of excess nucleotides and primers. Purified products were electrophoresed on a $0.8 \%$ agarose gel to ensure the presence of the product and determine its concentration. Between $10 \mathrm{ng}$ to $40 \mathrm{ng}$ of DNA were used in the sequencing reactions. Purified PCR products were used as the template for the PCR sequencing reaction (ABI Big-Dye ${ }^{\mathrm{TM}}$ Terminator Cycler Sequencing v3.0). The product of this reaction was purified and dried. Approximately half of the sequences were determined on an ABI Prism 310 Genetic Analyzer (Applied Biosystems, Inc.) at Ohio University. The other half was determined on an automated 3730 DNA Analyzer (Applied Biosystems, Inc.) at Ohio State University. All sequences will be deposited in the internet database GenBank. Voucher specimens for individuals sequenced will be deposited at Ohio University.

Sequences were read using Chromas v.1.45 or FinchTV v.1.3.0 and aligned for comparison using CLUSTALX v.1.81 (Jeanmougin et al. 1998). Due to the presence of repeat sequences and indels, control region sequence alignments were further adjusted manually. L. aepyptera ND3 and control region sequences were aligned with $L$. fluviatilis (the European River lamprey), L. appendix (the American brook lamprey) and Petromyzon marinus (the sea lamprey) (Genbank accession numbers, Appendix 2). L. fluviatilis is considered the sister taxon of L. aepyptera (Docker et al. 1999). I also 
sequenced three L. appendix individuals. These three species were used as outgroups in all analyses.

Analyses

The same individuals were sequenced for both the control region and ND3 gene. The ND3 and control region data sets were first analyzed individually then combined. Patterns of genetic structuring within and among L. aepyptera populations were determined with analysis of molecular variance (AMOVA) and hierarchical F statistics using Arlequin v.2.0 (Schneider et al. 2000). Sequence divergence was calculated and minimum spanning networks were manually constructed using Arlequin v.2.0 (Schneider et al. 2000). Saturation plots were produced using DAMBE (Xia and Xie 2001).

Modeltest uses log likelihood scores to determine the model of evolution that best fits the data (Posada and Crandal 1998). Modeltest v.3.7 (Posada and Crandal 1998) was used to determine the correct model of evolution for each data set. Determining the model of evolution best suited for the data is necessary since the maximum likelihood (ML) method is based on the parameter values of the model for which it uses to maximize the probability of the observed data (Huelsenbeck and Crandall 1997). The general time reversible model $(\mathrm{GTR}+\mathrm{G})$ was used for distance and $\mathrm{ML}$ analyses for all three data sets in PAUP* v.4.0 (Swofford 2000). Maximum likelihood parameters were based on the heuristic search option, 10 addition sequence replicates, and tree-bisectionreconnection (TBR) algorithm. Bootstrap values (Felsenstein 1985) were determined using a full heuristic search, with 100 pseudoreplicates, and 3 random addition sequence replicates. The distance analysis used was based on the neighbor-joining method. The 
neighbor-joining (NJ) method is a distance-based method that finds the shortest (minimum evolution) tree (Graur and Li 2000). Support for internodes was determined by bootstrap values (Felsenstein 1985) with 1000 pseudoreplicates.

PAUP* v.4.0 (Swofford 2000) was used for maximum parsimony (MP) analysis of each data set. Maximum parsimony analyses were based on unweighted parameters using the heuristic search option, 100 random addition sequence replicates, and TBR algorithm. Bootstrap values (Felsenstein 1985) were calculated using a full heuristic search, simple stepwise-addition option, TBR, and 1000 pseudoreplicates. 


\section{Results}

ND3

Between 1 and 4 individuals were sequenced from each population. The complete ND3 sequence comprised a total of 351 base pairs, the same as seen in other lamprey species (Lee and Kocher 1995; Docker et al. 1999). There were a total of 103 polymorphic sites with 48 parsimony informative sites. Nineteen unique haplotypes were detected from the 21 populations sampled. The AMOVA revealed significant differences among populations $(\mathrm{P}<0.001)$. Sequence divergences ranged from $0.0-6.3 \%$, and the mean sequence divergence was $4.2 \%$. The saturation plot suggested no evidence of transition or transversion saturation (Figure 6).

The minimum-spanning network identified 10 clades (Figure 7). A clade represents a haplotype or group of haplotypes that have fewer mutational steps between haplotypes within the group than between the group and other groups (Hardy et al. 2002). Typically, haplotypes within clades differed by 1 to 3 mutational steps, the exception being the Tennessee River clade that included populations separated by 9 and 10 mutational steps. Clades generally differed by 6 or more mutational steps. The 10 clades were highly differentiated and include: upper Ohio River, Atlantic slope, Obion River, Alabama, Mississippi, Missouri, Tennessee River, Tar Creek (Tennessee), Gaylor Creek (Tennessee), and Cumberland River (ND3 data set only; Docker et al. 1999). The Obion River populations, including the neotenic Terrapin Creek population, were highly differentiated from other populations. Tar Creek in the Forked Deer drainage 
immediately south of the Obion River differed from Obion River haplotypes by 15 mutation steps or more.

The same clades were evident in the neighbor-joining analysis (Figure 8). Relationships among clades and outgroups were poorly resolved as indicated by the low bootstrap values. Some of the relationships within the clades, however, were supported. The Yazoo River, Mississippi populations are from two tributaries, Kettle Creek and Yellow Leaf Creek, which are geographically very close and genetically similar as indicated by the high bootstrap value. The upper Ohio River clade was supported, although the relationships among these populations were not resolved. The two haplotypes sampled from tributaries in the Little Sandy River, Kentucky grouped together, as did the two haplotypes from southeastern Ohio. However, their relationship with each other and Camp Creek is unclear. Southeastern Ohio populations were collected in the Hocking River drainage (Appendix 1). The four populations sampled from the Tennessee River formed an unsupported clade. Little Bear Creek and Weatherford Creek, both located in the middle Tennessee River, were more closely related to each other than to the two populations sampled from the lower Tennessee River, Bear Creek and McCollough Fork. The clade representing the Obion River populations, including Terrapin Creek, was highly supported. The relationship between Atlantic slope populations in Maryland and the Neuse River, North Carolina were also supported by high bootstrap values.

Parsimony analysis resulted in 6 most parsimonious trees. A strict consensus tree is reported (Figure 9) that supports the same clades evident in the neighbor-joining tree 
with the major difference being that $L$. appendix was included as an outgroup with $P$. marinus. Relationships among clades and outgroups, however, were not well supported. Maximum likelihood analysis using the GTR $+\mathrm{G}$ model of sequence evolution resulted in 2 trees with a likelihood score of $-\ln \mathrm{L}=980.0$. A strict consensus tree (Figure 10) indicated the same intradrainage/geographic relationships noted in the previous analyses. The relationships among clades and outgroups were not well supported.

\section{Control Region}

Approximately, 650 base pairs spanning control region sequence I were sequenced. The total number of bases varied due to the presence of tandem copies of a 39-base pair repeat. In addition to the repeats, several small indels (1-8 bases) were also detected just upstream of the repeats. Due to the variability in repeat number and the difficulty in aligning the indel region, both were left out of the analyses, leaving 340 base pairs of unique control region sequence (approximate base pairs used in analyses: 1-41; 311-610). The unique region aligned well with L. fluviatilis, L. appendix, and Petromyzon marinus (Genbank accession nos., Appendix 2). Most of the variation was characterized by nucleotide substitutions.

Of the 340 base pairs analyzed, there were 76 polymorphic sites of which 56 were parsimony informative. Nineteen unique haplotypes were identified. The AMOVA analysis detected significant differences among populations $(\mathrm{P}<0.001)$. Sequence divergence ranged from 0.0 to $14.4 \%$, and the mean sequence divergence was approximately $4.8 \%$. The saturation plot revealed no evidence of transition or 
transversion saturation (Figure 11). The minimum-spanning network revealed highly differentiated haplotypes (Figure 12). The clades identified with the ND3 gene were the same for the control region (with the exception of Cumberland River, for which no sequence was available). Haplotypes within a clade generally differed by 1 to 6 mutations. The Tennessee River clade exhibited a wider range of mutational differences, from 4 to 21, among its haplotypes. The Tennessee River haplotypes grouped together despite the large number of mutational steps between haplotypes. Additional haplotypes were detected in the Schultz River, Alabama population (2 haplotypes) and Gaylor Creek, Tennessee population (3 haplotypes). Only one unique haplotype from the Schultz River and one unique haplotype from Gaylor Creek were reported for the same individuals sequenced in the ND3 data set.

The neighbor-joining, MP, and ML analyses revealed results (Figures 13-15) similar to the ND3 analyses. The same clades were present, however, their relationships with each other and with the outgroups were unresolved. Two additional differences from the ND3 analyses were revealed, the first being a well-supported Tennessee River clade. Weatherford Creek and Little Bear Creek, middle Tennessee River populations, are sister to the lower Tennessee River populations. However, relationships within the lower Tennessee River and between the lower and middle Tennessee River populations were not resolved in the MP and ML analyses. The second difference is the connection of the Little Sandy River populations with Camp Creek, which are sister to the southeastern Ohio clade. This relationship was supported by high bootstrap values and 
was evident in all three analyses. This relationship does not appear in the MP tree (Figure 14) shown but is evident in the MP bootstrap consensus tree (not shown).

\section{Combined ND3/Control Region Data Set}

The combined ND3/control region data set resulted in a total of 691 base pairs with 176 polymorphic sites of which 114 sites were parsimony informative. There were 23 haplotypes. The AMOVA analysis resulted in significant differences among populations $(\mathrm{P}<0.001)$. The minimum-spanning network of the combined data revealed similar results to the individual data sets (Figure 16). The same clades were evident in the minimum-spanning network and the neighbor-joining, MP and ML analyses (Figures 17-19) and include the following well-supported clades: Tennessee River, upper Ohio River, Obion River, Atlantic slope, Yazoo River, Gaylor Creek, and Schultz Creek, and the remaining clades that contain 1 unique haplotype. The neighbor-joining, MP and ML analyses suggested that the relationships among the clades and the outgroups were not resolved. 


\section{Discussion}

\section{Control Region}

The control region contains non-coding sequences and is thought to be the origin of leading-strand replication in the mitochondrial genome (Clayton 2003). The control region of most vertebrates is composed of a continuous sequence with an internally conserved region flanked by more variable regions (Brown 1986; Faber and Stepien 1998). The European lamprey, Lampetra fluviatilis, (Delarbe et al. 2000) and the sea lamprey, Petromyzon marinus, (Lee and Kocher 1995), however, contain two separate regions that correspond to the control region. Delarbre et al. (2000) suggested that this pattern is a synapomorphy in lampreys. The two non-coding regions are separated by two tRNA genes, threonine and glutamate, that are normally found between the ND6 and cyt $b$ genes (Lee and Kocher 1995). This structural organization is different than that seen in other vertebrates (Fumagalli et al. 1996; Broughton and Dowling 1997; Faber and Stepien 1998). It is thought that the first segment of the lamprey control region contains most of the regulatory sequences for replication (Lee and Kocher 1995).

L. aepyptera exhibited control region sequences that aligned with $L$. fluviatilis, $L$.

appendix and Petromyzon marinus. Variation in the analyzed region of the control region consisted of nucleotide substitutions. The analyses conducted with the ND3 and control region data sets presented similar results.

Phylogeny and Genetic Variation in Lampetra aepyptera

Lampetra aepyptera populations exhibit significant phylogeographic structuring and are comprised of highly differentiated clades. These clades were evident in the 
minimum-spanning network, neighbor-joining, ML and MP analyses for each data set. The 10 clades identified are associated with different drainages and/or geographic locations within drainages and include: upper Ohio River, Atlantic slope, Obion River, Alabama, Mississippi, Missouri, Tennessee River, Tar Creek (Tennessee), Gaylor Creek (Tennessee), and Cumberland River (ND3 data set only). The AMOVA results suggest highly significant differentiation among populations. Although intrapopulation variation appeared low, a possible consequence of small sample sizes, each drainage sampled contained a unique haplotype with the exception of the southeastern Ohio populations. These populations included a possibly widespread haplotype and its derivatives. Relationships among the 10 clades identified were not resolved. Phylogeography

Powers et al. (2004) reported a mean sequence divergence of $1.2 \%$ (cyt b) for populations of Etheostoma cinereum sampled in the Cumberland and Tennessee Rivers and suggested that populations be considered distinct management units. Switzer and Wood (2002) reported a mean sequence divergence of $7.18 \%$ (cyt $b$ ) between populations of Etheostoma tetrazonum in the Meramec River and the Moreau, Osage, and Gasconade River drainages. They suggested that these two monophyletic groups represent two separate species.

The high level of sequence divergence for L. aepyptera in both the control region and ND3 sequences suggests populations have been diverging for a long period of time. Because L. aepyptera exhibits limited dispersal (Seversmith 1953), it is likely that populations from different drainages have had little or no contact with each other for 
some time. If we employ a standard vertebrate molecular clock of $2 \%$ sequence divergence per million years (Avise et al. 1998; Hardy et al. 2002) for the mean sequence divergences (4.2\%-ND3; 4.8\%-control region), it suggests that much of the diversification occurred during the late Pliocene or early Pleistocene (2.1-2.4 MYA). A more conservative poikilothermic clock estimate $(0.5 \%-1.3 \%$ sequence divergence per million years; Hardy et al. 2002) based on the mean sequence divergences of both data sets suggests that diversification occurred in the late Miocene (8.4-9.6 MYA based on 0.5\%) or Pliocene (3.2 -3.7 MYA based on 1.3\%). A molecular clock used with other information including phylogenetic relationships and geologic events can provide useful information but should not be used as the primary source for the timing of cladogenesis (Strange and Burr 1997). It is thought that the control region generally mutates faster than other mitochondrial regions (Faber and Stepien 1997). Differences in sequence divergence between ND3 and the control region suggest that these two data sets are not under the same constraints. ND3 is a coding region and evolution at this gene would be constrained by the function of the protein product. The control region is non-coding and would not be so constrained.

The events responsible for the diversification in L. aepyptera could not be determined from this study. Polytomies formed by the lack of resolution among clades in the neighbor-joining, MP and ML analyses for each data set suggest two possibilities. First, there are not sufficient informative characters to resolve the relationships. A second explanation is that diversification among the L. aepyptera clades occurred rapidly over a short time period. Events that occurred during the late Miocene, Pliocene and 
Pleistocene, including sea level fluctuations and glaciations, could have provided conditions conducive to significant diversification (Near et al. 2003). There is evidence that a great deal of intra- and interspecific variation in other species occurred during these periods (Hewitt 1996; Avise and Walker 1998; Avise et al. 1998; Near et al. 2001; Near et al. 2003; Near and Keck 2005). Near et al. (2003) attributed fluctuations in sea levels during the late Miocene and Pliocene to several speciation events in North American black basses in the genus Micropterus and suggested that all intraspecific variation in Micropterus could be dated to the Pleistocene. Sequence divergence between $L$. aepyptera clades suggests a rapid diversification during the late Miocene or Pliocene. Furthermore, sequence divergence within some clades suggests a more recent Pleistocene diversification. The Pleistocene-induced intraspecific phylogeographic structuring model (Hewitt 1996) describes the fragmentation and differentiation of populations during the Pleistocene (Near et al. 2003), a time period that has played a major role in shaping intraspecific genetic diversity (Avise et al. 1998; Bernatchez and Wilson 1998). It is probable that a series of events have contributed to the intraspecific variation evident in L. aepyptera, including vicariance, isolation, and dispersal events.

The Mississippi Basin has been the center of North American fish distribution, refuge, dispersal and diversification (Hocutt 1979; Robison 1986). The old Mississippi River fauna comprised fish common to Europe, northern Asia and North America and included lampreys (Robison 1986). Stability of the Mississippi River has enabled fish populations in different drainages to become isolated and diversify (Robison 1986). It is probable that the distribution of L. aepyptera has waxed and waned as a result of geologic 
events that occurred during the Miocene, Pliocene and Pleistocene, including incursions of the Gulf of Mexico into the Mississippi Embayment and glaciations (Robison 1986) (Figure 20). Populations in the Mississippi Basin have experienced little gene flow between drainages as indicated by high sequence divergences between clades, with the exception of the upper Ohio River clade.

Populations sampled in the Obion River, including Terrapin Creek, are highly differentiated from other populations. High sequence divergence (ND3-4.3\%) between the Obion River and Tar Creek, a tributary of the Forked Deer immediately south of the Obion River, and other populations suggests long-term isolation. The extent of neoteny in the Obion River and surrounding drainages and the cause of variation in ontogenic development as compared to other L. aepyptera populations is unclear. Neoteny may have arisen in response to conditions present in the Obion River (Walsh and Burr 1981). Another possibility is that neoteny arose in the Obion River by chance and because little gene flow occurs between adjacent drainages, neoteny has remained in the Obion River. An additional hypothesis is that neoteny may be the result of a founder event where a neotenic founder(s) became isolated in the Obion River and diversified from populations in other drainages. Neoteny has been recorded in L. zanandreai (Zanandrea 1957; 1961) and L. lethophaga (Hubbs 1971). Whether populations from the Obion River constitute an undescribed species remains to be determined. No specimens collected from Obion River tributaries were fully metamorphosed. Fully metamorphosed adults were collected from the surrounding drainages. Populations from the Obion River, Tar Creek (Forked 
Deer Drainage), and Gaylor Creek (Hatchie River Drainage) are geographically close and exhibit considerable genetic differentiation.

Although the position of the Little Black River, Missouri population remains unresolved, there is evidence for a relationship with the Gaylor Creek, Tennessee population that suggests a recent, possibly Pleistocene, dispersal from western Tennessee. Drake (2002) observed relatively high genetic similarity between these two populations. The connection between these populations may be explained by two dispersal hypotheses. The ancestral Mississippi River was located west of its current location and west of Crowley's Ridge (Burr and Page 1986; Robison 1986). The Ridge breached at Thebes, Illinois during the Pleistocene subsequently diverting the Mississippi River to its present course (Robison 1986). This may explain the distribution of populations west of the Mississippi River that were separated from Tennessee populations. A second hypothesis suggests that some fishes dispersed over the Mississippi River during glacial periods when the Mississippi River was lower and appropriate habitat was present (Burr and Warren 1986; Robison 1986). This may be a likely explanation for fishes that dispersed from the Tennessee and Cumberland Rivers that were south of the former Teays River drainage and from the White and Arkansas drainages west of the Mississippi River below the Missouri River (Burr and Warren 1986). The disjunct distribution of the telescope shiner (Notropis telescopus) east and west of the Mississippi River supports the latter hypothesis (Burr and Warren 1986).

The Tennessee River clade exhibited considerable genetic variation among populations from the middle and lower Tennessee River. Bear Creek and McCollough 
Fork, both lower Tennessee River populations are the closest geographically and showed the least amount of differentiation among the four populations. The mean sequence divergence between the lower and middle Tennessee River populations was $2.7 \%$ (ND3), suggesting isolation since the Pliocene. This pattern of genetic variation in a single drainage suggests limited gene flow and dispersal between populations. Populations of the Ashy darter (Etheostoma cinereum) sampled from the upper and lower Tennessee River exhibited genetic differentiation with a mean sequence divergence of $2.2 \%$ (cyt $b$; Powers et al. 2004).

The upper Ohio River clade exhibited limited genetic structuring as compared to the formerly mentioned clades in the Mississippi River Basin. The relationships of the upper Ohio River populations, including the southeastern Ohio populations, Camp Creek and the Little Sandy River populations in Kentucky, suggest a range expansion into previously glaciated regions. The relationship between the Little Sandy River populations and Camp Creek, which are sister to the southeastern Ohio populations, suggests a range expansion from southern refugia. Sequence divergence suggests dispersal occurred sometime during the Pleistocene. Because the haplotypes found in these areas appear to be derivatives of a similar haplotype, this may be the result of a number of founders that expanded their range (Avise 2001) following the retreat of glaciers. Expansions into once glaciated regions usually result in lower levels of intraspecific differentiation relative to species or populations from nonglaciated areas (Bernatchez and Wilson 1998). Populations of Percina evides and Hypentelium nigricans sampled from previously glaciated regions exhibited limited phylogeographic 
structuring and shallow genetic divergences (Near et al. 2001; Berendzen et al. 2003). The patterns observed in the upper Ohio River Lampetra aepyptera populations suggest that the retreat of the glaciers exposed appropriate habitat, resulting in a northward dispersal.

The relationship between Atlantic slope populations from the Neuse River, North Carolina and Maryland suggest these populations are more closely related to each other than to populations west of the Blue Ridge. Sequence divergence (1.7\% for ND3; $1.4 \%$ for control region) suggests a relatively recent dispersal event between these populations during the late Pliocene or early Pleistocene, and may represent a dispersal event across the Blue Ridge and subsequent migration north or south along the Coastal Plain. Several species of fish exhibit an intra- or interspecific sister relationship between populations in the Mississippi and Mobile Basin drainages and populations in the Atlantic slope drainages that suggests dispersal over the Blue Ridge (Berendzen et al. 2003).

The Mississippi/Atlantic slope divide is in the Blue Ridge Mountains (Hocutt et al. 1986), which extends from Pennsylvania to north-eastern Georgia (Thornbury 1965). The divide has been moving north and west due to the short, steep nature of Atlantic slope streams (Hocutt 1979; Hocutt et al. 1986). The Roanoke, James and Potomac Rivers have breached the Blue Ridge (Hocutt et al. 1986). The presence of L. aepyptera on the Atlantic slope may be explained by stream capture events from the Teays River system in Virginia via dispersal through the Gauley River (Hocutt 1979). Dispersal to the Atlantic slope from the Teays River may have occurred directly from the GauleyGreenbrier Rivers across the divide to the James-Roanoke Rivers or indirectly via the 
Gauley-Greenbrier-Fincastle Rivers (Hocutt 1979). Lee (1976) suggested L. aepyptera dispersed via headwater captures through Virginia and expanded north along the Coastal Plain prior to the development of the Chesapeake Bay, which is thought to be less than 15,000 years old. The Greater Susquehanna channel once occupied the present location of the Chesapeake Bay and during glacial periods, reduced sea levels facilitated the movement of species thought to inhabit more upland regions, such as L. aepyptera. (Hocutt et al. 1986). Stream capture and interconnection of drainages were likely paths for dispersal of Atlantic slope fishes along the coast (Hocutt et al.1986) and may explain the distribution of L. aepyptera in this region.

Another possible dispersal route across the Blue Ridge is the upper Tennessee River system with the New River and subsequent stream capture events with Atlantic slope drainage systems. There is evidence that stream capture events have occurred between the upper Tennessee River tributaries and the New River and with the New River and the Roanoke River (Hocutt et al. 1986 and citations therein). However, there is no evidence that L. aepyptera populations have ever existed in the Roanoke River. The presence of L. aepyptera populations in the Tar and Neuse Rivers suggests, however, that lateral stream captures may have occurred with the Roanoke River. Few rivers have breached the Blue Ridge south of the Roanoke River (Hocutt et al. 1986), suggesting that dispersal from another river other than the Roanoke River would have been unlikely. During the Pleistocene, the Continental Shelf was exposed, connecting the Tar and Neuse Rivers that formed the Greater Pamlico River (Hocutt et al. 1986). This could have provided a dispersal route for L. aepyptera into both drainages. 


\section{Conclusion}

Lampetra aepyptera is a widespread North American species that exhibits significant intraspecific phylogeographic structuring based on drainage and/or geographic location. Differentiation among populations and some geographic regions is high, suggesting limited gene flow over a considerable length of time. Although clade relationships were not able to be resolved in this study, the distribution of L. aepyptera is likely the result of vicariance, isolation and dispersal events. This study identified 10 well-differentiated clades.

Upper Ohio River populations are likely the result of a range expansion event into previously glaciated regions. Atlantic slope populations from Maryland and North Carolina exhibited relatively low divergence and suggest a recent dispersal along the Atlantic coast. The four populations sampled from the lower and middle Tennessee River suggest limited intra-drainage gene flow. Obion River populations, including the neotenic Terrapin Creek population, are highly differentiated from other L. aepyptera populations, suggesting long-term isolation.

The mean sequence divergence for the ND3 gene and the control region suggests that much of the diversification in L. aepyptera occurred during the late Miocene or Pliocene, a time marked by significant sea level fluctuations, based on a molecular clock of $0.5-1.3 \%$ sequence divergence per million years (Hardy et al. 2002). The inability to resolve clade relationships suggests a rapid diversification during this period. Sequence divergence within some clades suggests events occurring during the Pleistocene may have also played a role in diversification. L. aepyptera may represent several 
undescribed species. Additional data, including additional sampling, sequence data and morphological data, may resolve relationships and species limits within L. aepyptera. 


\section{Works Cited}

Abbott CC (1860) Description of new species of American fresh-water fishes. No. 5 Ammocoetes aepyptera Abbott. Proceedings of the Academy of Natural Sciences of Philadelphia, 12, 327-328.

Avise JC (2001) Phylogeography: the history and formation of species. Harvard University Press, Cambridge.

Avise JC, Arnold J, Ball RM, Bermingham E, Lamb T, Neigel JE, Reeb CA, Saunders NC (1987) Intraspecific Phylogeography: The mitochondrial DNA bridge between population genetics and systematics. Annual Review of Ecology and Systematics, 18, 489-522.

Avise JC, Felley J (1978) Population structure of freshwater fishes I. Genetic variation of bluegill (Loomis marchers) populations in manmade reservoirs. Evolution, 33, $15-26$.

Avise JC, Walker D (1998) Pleistocene phylogeographic effects on avian populations and the speciation process. Proceedings of the Royal Society of London, 265, 457463.

Avise JC, Walker D, Johns GC (1998) Speciation durations and Pleistocene effects on vertebrate phylogeography. Proceedings of the Royal Society of London, 265, 1707-1712.

Bailey RM (1980) Comments on the classification and nomenclature of lampreysalternative view. Canadian Journal of Fisheries and Aquatic Sciences, 37, 16261629.

Berendzen PB, Simons AM, Wood RM (2003) Phylogeography of the northern hog sucker, Hypentelium nigricans (Teleported: Cypriniformes): genetic evidence for the existence of the ancient Teays River. Journal of Biogeography, 30, 11391152 .

Bernatchez L, Wilson CC (1998) Comparison phylogeography of Nearctic and Palearctic fishes. Molecular Ecology, 7, 431;-452.

Burr BM, Page LM (1986) Zoogeography of fishes of the Lower Ohio-Upper Mississippi Basin. In: The Zoogeography of North American Freshwater Fishes (ed. Hocutt CE, Wiley EO), pp. 287-324. John Wiley \& Sons, Inc., New York. 
Burr BM, Warren ML (1986) A Distributional Atlas of Kentucky Fishes. Kentucky Nature Preserves Commission Scientific and Technical Series Number 4, Kentucky.

Briggs JC (1986) Introduction to the zoogeography of North American fishes. In: The Zoogeography of North American Freshwater Fishes (eds. Hocutt CE, Wiley EO), pp. 1-16. John Wiley \& Sons, Inc., New York.

Broughton RE, Dowling TE (1997) Evolutionary dynamics of tandem repeats in the mitochondrial DNA control region of the minnow Cyprinella spiloptera. Molecular Biology and Evolution, 14, 1187-1196.

Brown, GG (1986) Structural conservation and variation in the D-loop-containing region of vertebrate mitochondrial DNA. Journal of Molecular Biology, 192, 503-511.

Chenoweth SF, Hughes JM (1997) Genetic population structure of the catadromous Perciform: Macquaria novemaculeata (Percichthyidae). Journal of Fish Biology, $50,721-733$.

Clayton DA (2003) Mitochondrial DNA replication: what we know. Life, 55, 213-217.

Docker MF, Youson JH, Beamish RJ, Devlin RH (1999) Phylogeny of the lamprey genus Lampetra inferred from mitochondrial cytochrome $b$ and ND3 gene sequences. Canadian Journal of Fisheries and Aquatic Sciences, 56, 2340-2349.

Delarbre C, Escriva H, Gallut C, Barriel V, Kourilsky P, Janvier P, Laudet V, Gachelin G (2000) The complete nucleotide sequence of the mitochondrial DNA of the Agnathan Lampetra fluviatilis: bearings on the phylogeny of cyclostomes. Molecular Biology and Evolution, 17, 519-529.

Drake AT (2002) Evolution and Patterns of Genetic Variation in the Least Brook Lamprey, Lampetra aepyptera. Masters Thesis, Ohio University.

Faber JE, Stepien CA (1997) The utility of mitochondrial DNA control region sequences for analyzing phylogenetic relationships among populations, species, and genera of the Percidae. In: Molecular Systematics of Fishes (ed. Stepian CA), pp. 129143. Academic Press, San Diego.

Faber JE, Stepien CA (1998) Tandemly repeated sequences in the mitochondrial DNA control region and phylogeography of the pike-perches Stizostedion. Molecular Phylogenetics and Evolution, 10, 310-322.

Felsenstein J (1985) Confidence limits on phylogenies: An approach using the bootstrap. Evolution, 39, 783-791. 
Froufe E, Knizhin I, Koskinen MT, Primmer CR, Weiss S (2003) Identification of reproductively isolated lineages of Amur grayling (Thymallus grubii Dybowski 1869): Concordance between phenotypic and genetic variation. Molecular Ecology, 12, 2345-2355.

Froufe E, Knizhin I, Weiss S (2005) Phylogenetic analysis of the genus Thymallus (grayling) based on mtDNA control region and ATPase 6 genes, with inferences on control region constraints and broad-scale Eurasian phylogeography. Molecular Phylogenetics and Evolution, 34, 106-117.

Fumagalli L, Taberlet P, Favre L. Hausser J (1996) Origin and evolution of homologous repeated sequences in the mitochondrial DNA control region of shrews. Molecular Biology and Evolution, 13, 31-46.

Funk VA (1986) Revolutions in Historical Biogeography. In: Foundations of Biogeography: Classic Papers with Commentaries (ed. Lomolino MV, Sax DF, Brown JH), pp. 647. The University of Chicago Press, Chicago.

Gilbert CR (1976) Composition and derivation of the North American freshwater fish fauna. Florida Scientist, 39, 104-111.

Giller PS, Myers AA, Riddle BR (1986) Earth History, Vicariance, and Dispersal. In: Foundations of Biogeography: Classic Papers with Commentaries (ed. Lomolino MV, Sax DF, Brown JH), pp. 267. The University of Chicago Press, Chicago.

Graur D, Li W-H (2000) Fundamentals of Molecular Evolution, $2^{\text {nd }}$ edn. Sinauer Associates, Sunderland.

Hardy, ME, Grady JM, Routman EJ (2002) Intraspecific phylogeography of the slender madtom: the complex evolutionary history of the Central Highlands of the United States. Molecular Ecology, 11, 2393-2403.

Hewitt GM (1996) Some genetic consequences of ice ages, and their role in divergence and speciation. Biological Journal of the Linnaen Society, 58, 247-276.

Hocutt CH (1979) Drainage evolution and fish dispersal in the central Appalachians. Geological Society of America Bulletin, 90, 197-234.

Hocutt CH, Jenkins RE, Stauffer JR (1986) Zoogeography of the fishes of the Central Appalachians and Central Atlantic coastal plain. In: The Zoogeography of North American Freshwater Fishes (ed. Hocutt CE, Wiley EO), pp. 161-211. John Wiley \& Sons, Inc., New York. 
Howard JH (1993) Allozyme variation in the Mottled sculpin (Cottus bairdi): A test of stream capture hypotheses. Copeia, 3, 870-875.

Howell WM and Jenkins R (1999) Vertebrate zoology class photos. Samford University, http://www.samford.edu/schools/artsci/biology/vert-zoo-99s.htm

Hubbs CL (1971) Lampetra (Entosphenus) lethophaga, a new species, the nonparasitic derivative of the Pacific lamprey. Transaction of the San Diego Society of Natural History, 16, 125-163.

Huelsenbeck JP, Crandall KA (1997) Phylogeny estimation and hypothesis testing using maximum likelihood. Annual Review of Ecology and Systematics, 28, 437-466.

Jeanmougin F, Thompson JD, Gouy M, Higgins DG, Gibson TJ (1998) Multiple sequence alignment with CLUSTALX. Trends in Biochemical Sciences, 23, 403405.

Johnson SG (2005) Age, phylogeography and population structure of the microendemic banded spring snail, Mexipyrgus churinceanus. Molecular Ecology, 14, 22992311.

Jordan DS, Evermann BW, Clark HW (1930) Checklist of the fishes and fishlike vertebrates in North and Middle America north of the northern boundary of Venezuela and Columbia. Report of the United States Commissioner of Fisheries for the fiscal year 1928 with Appendixes, Part II U.S. Government Printing Office, Washington, 1-670.

Kuchta SR, Tan A (2005) Isolation by distance and post-glacial range expansion in the rough-skinned newt, Taricha granulose. Molecular Ecology 14, 225-244.

Lee DS (1976) Aquatic zoogeography of Maryland. Atlantic Naturalist, 31, 147-158.

Lee W-J, Kocher TD (1995) Complete sequence of a sea lamprey (Petromyzon marinus) mitochondrial genome: early establishment of the vertebrate genome organization. Genetics, 139, 873-887.

Mayden RL (1988) Vicariance biogeography, parsimony, and evolution in North American freshwater fishes. Systematic Zoology, 37, 329-355.

NatureServe. 2003. NatureServe. 2005. NatureServe Explorer: An online encyclopedia of life [web application]. Version 4.5. NatureServe, Arlington, Virginia. Available http://www.natureserve.org/explorer. (Accessed: October 18, 2005 ). 
Near TJ, Kassler TW, Koppelman JB, Dillman CB, Philipp DP (2003) Speciation in North American black basses, Micropterus (Actinopterygii: Centrarchidae). Evolution, 57, 1610-1621.

Near TJ, Keck BP (2005) Dispersal, vicariance, and timing of diversification in Nothonotus darters. Molecular Ecology, 14, 3485-3496.

Near TJ, Page LM, Mayden RL (2001) Intraspecific phylogeography of Percina evides (Percidae: Etheostomatinae): an additional test of the Central Highlands prePleistocene vicariance hypothesis. Molecular Ecology, 10, 2235-2240.

Ohio Department of Natural Resources (2005) Life history notes: Least Brook Lamprey. http://www.dnr.state.oh.us/wildlife/Fishing/aquanotes-fishid/lbrampry.htm

Page LM, Burr BM (1991) A Field Guide to Freshwater Fishes. Houghton Mifflin Company, New York.

Powers SL, Mayden RL, Etnier DA (2004) Conservation genetics of the Ashy darter, Etheostoma cinereum (Percidae: Subgenus Allohistium), in the Cumberland and Tennessee Rivers of the southeastern United States. Copeia, 3, 632-637.

Posada D, Crandall KA (1998) MODELTEST: testing the model of DNA substitution. Bioinformatics, 14, 817-818.

Rohde FC, Arndt RG, Wang JCS (1976) Life history of the freshwater lampreys, Okkelbergia aepyptera and Lampetra lamottenii (Pisces: Petromyzonidae), on the Delmarva Peninsula (East Coast, United States). Bulletin Southern California Academy of Sciences, 75,99-111.

Robison HW (1986) Zoogeographic implications of the Mississippi River basin. In: The Zoogeography of North American Freshwater Fishes (ed. Hocutt CE, Wiley EO), pp. 267-285. John Wiley \& Sons, Inc., New York.

Ruedi M, Smith MF, Patton JL (1997) Phylogenetic evidence of mitochondrial DNA introgression among pocket gophers in New Mexico (family Geomyidae). Molecular Ecology, 6, 453-462.

Ruokonen M, Aarvak T, Madsen J (2005) Colonization history of the high-arctic pinkfooted goose Anser brachyrhynchus. Molecular Ecology, 14, 171-178.

Salzburger W, Brandstaetter A, Gilles A, Parson W, Hempel M, Sturmbauer C, Meyer A (2003) Phylogeography of the vairone (Leuciscus souffia, Risso 1826) in Central Europe. Molecular Ecology, 12, 2371-2386. 
Schneider S, Roessli D, Excofier L (2000) Arlequin: A software for population genetics data analysis, ver 2.000. Genetics and Biometry Lab, Department of Anthropology, University of Geneva.

Seversmith HF (1953) Distribution, morphology and life history of Lampetra aepyptera, a brook lamprey, in Maryland. Copeia, 4, 225-232.

Starkey DE, Shaffer HB, Burke RL, Forstner MR, Iverson JB, Janzen FJ, Rhodin AGJ, Ultsch GR (2003) Molecular systematics, phylogeography, and the effects of Pleistocene glaciation in the painted turtle (Chrysemys picta) complex. Evolution, 57, 119-128.

Stefanni S, Thorley JL (2003) Mitochondrial DNA phylogeography reveals the existence of an Evolutionary Significant Unit of the sand goby Pomatoschistus minutus in the Adriatic (Eastern Mediterranean). Molecular Phylogenetics and Evolution, 28, 601-609.

Stilwell JM (1974) The life history of an isolated spawning population of least brook lamprey, Lampetra aepyptera (Abbott). Masters Thesis. Ohio State University.

Strange RM (1998) Mitochondrial DNA variation in Johnny darters (Pisces: Percidae) from Eastern Kentucky supports stream capture for the origin of Upper Cumberland River fishes. American Midland Naturalist, 140, 96-102.

Strange RM, Burr BM (1997) Intraspecific phylogeography of North American highland fishes: A test of the Pleistocene vicariance hypothesis. Evolution, 51, 885-897.

Switzer JF, Wood RM (2002) Molecular systematics and historical biogeography of the Missouri saddled darter Etheostoma tetrazonum (Actinopterygii: Percidae). Copeia, 2, 450-455.

Swofford DL (2000) PAUP* Phylogenetic Analysis Using Parsimony (*and Other Methods, Version 4.0*. Sinauer Associates, Sunderland.

Thornbury WD (1965) Regional Geomorphology of the United States. Wiley and Sons, New York.

Turner TF, Trexler JC, Kuhn DN, Robison HW (1996) Life-history variation and comparative phylogeography of darters (Pisces: Percidae) from the North American Central Highlands. Evolution, 50, 2023-2036.

Vladykov VD, Kott E (1976) Is Okkelbergia Creaser and Hubbs, 1922 (Petromyzonidae) a distinct taxon? Canadian Journal of Zoology, 54, 421-425. 
Vladykov VD, Kott E, Pharand-Coad S (1975) A new nonparasitic species of lamprey, genus, Lethenteron (Petromyzonidae), from eastern tributaries of the Gulf of Mexico. U.S.A National Museum of Natural Sciences Publication in Zoology, $12,1-36$.

Walsh SJ, Burr BM (1981) Distribution, morphology and life history of the Least brook lamprey, Lampetra aepyptera (Pisces: Petromyzontidae), in Kentucky. Brimleyana, 6, 83-100.

Wood RM, Raley ME (2000) Cytochrome $b$ sequence variation in the crystal darter Crystallaria asprella (Actinopterygii: Percidae). Copeia, 1, 20-26.

Xia X, Xie Z (2001) DAMBE: Software package for data analysis in molecular biology and evolution. The Journal of Heredity, 92, 371-373.

Youson JH ((1997) Is lamprey metamorphosis regulated by thyroid hormones? American Zoology, 37, 441-460.

Zanandrea G (1957) Neoteny in a lamprey. Nature, 179, 925-926.

Zanandrea G (1961) Studies in European lampreys. Evolution, 15, 523-534. 


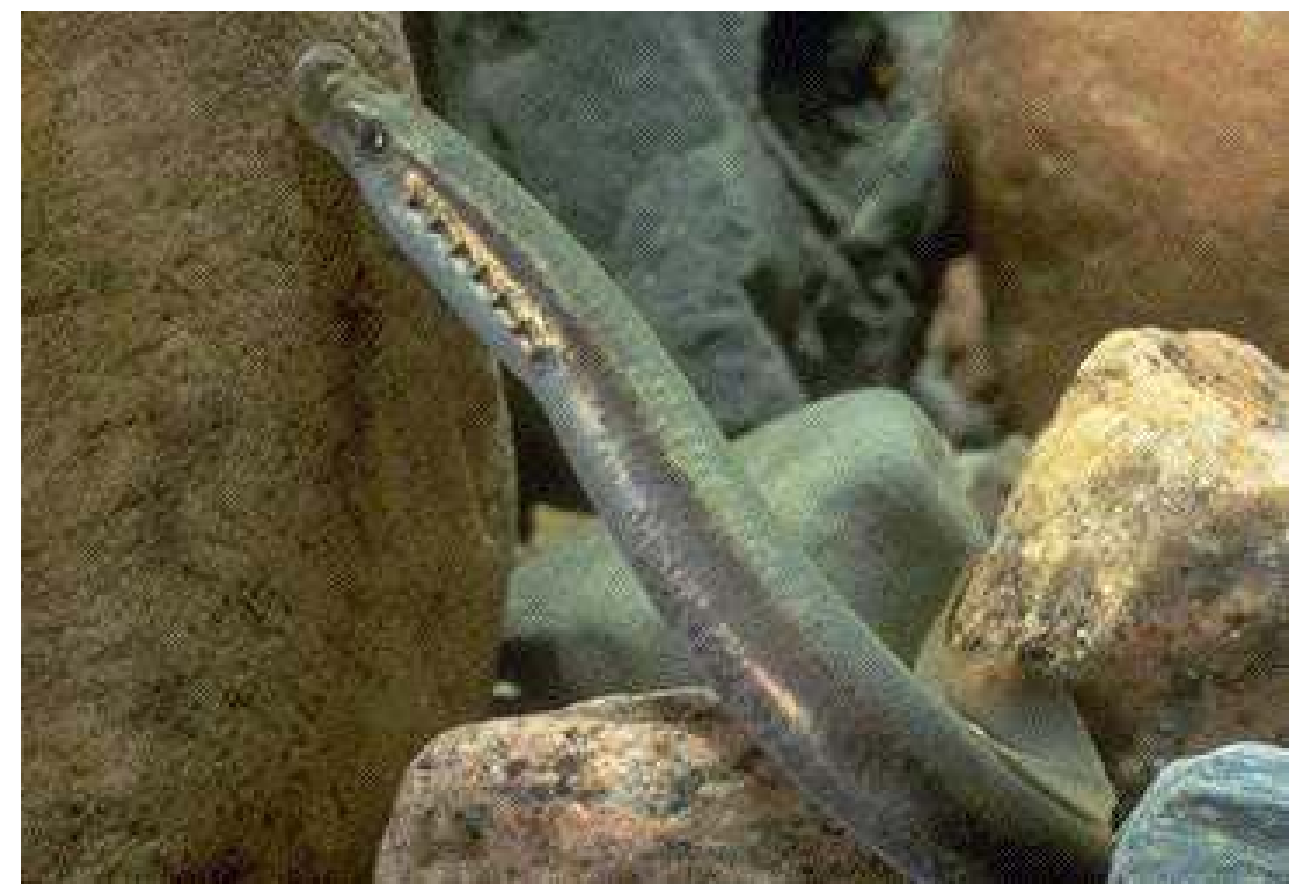

Figure 1. The Least Brook Lamprey, Lampetra aepyptera (Photograph from the Ohio Department of Natural Resources 2005).

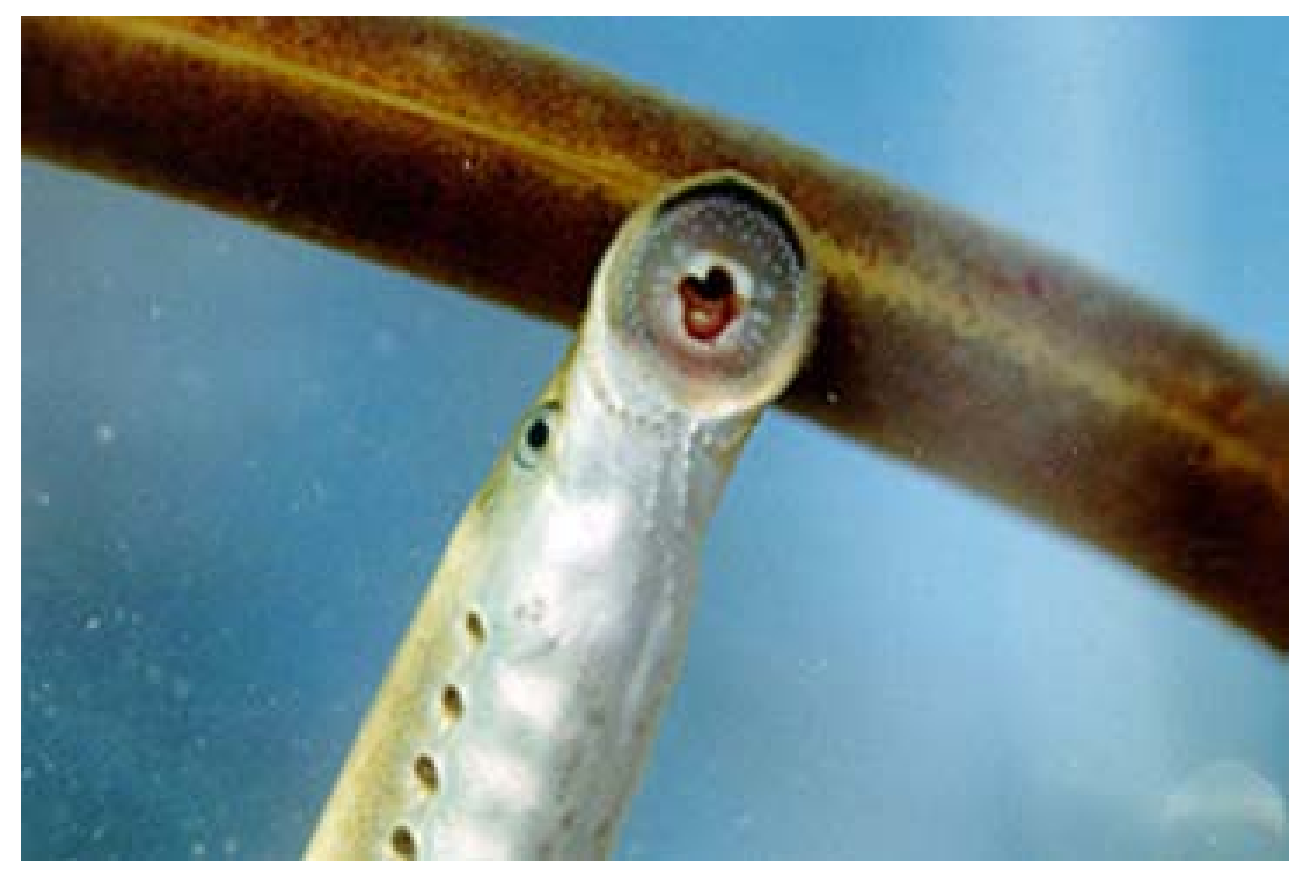

Figure 2. Close-up of the Least Brook Lamprey, Lampetra aepyptera (Photograph by Howell and Jenkins 1999). 


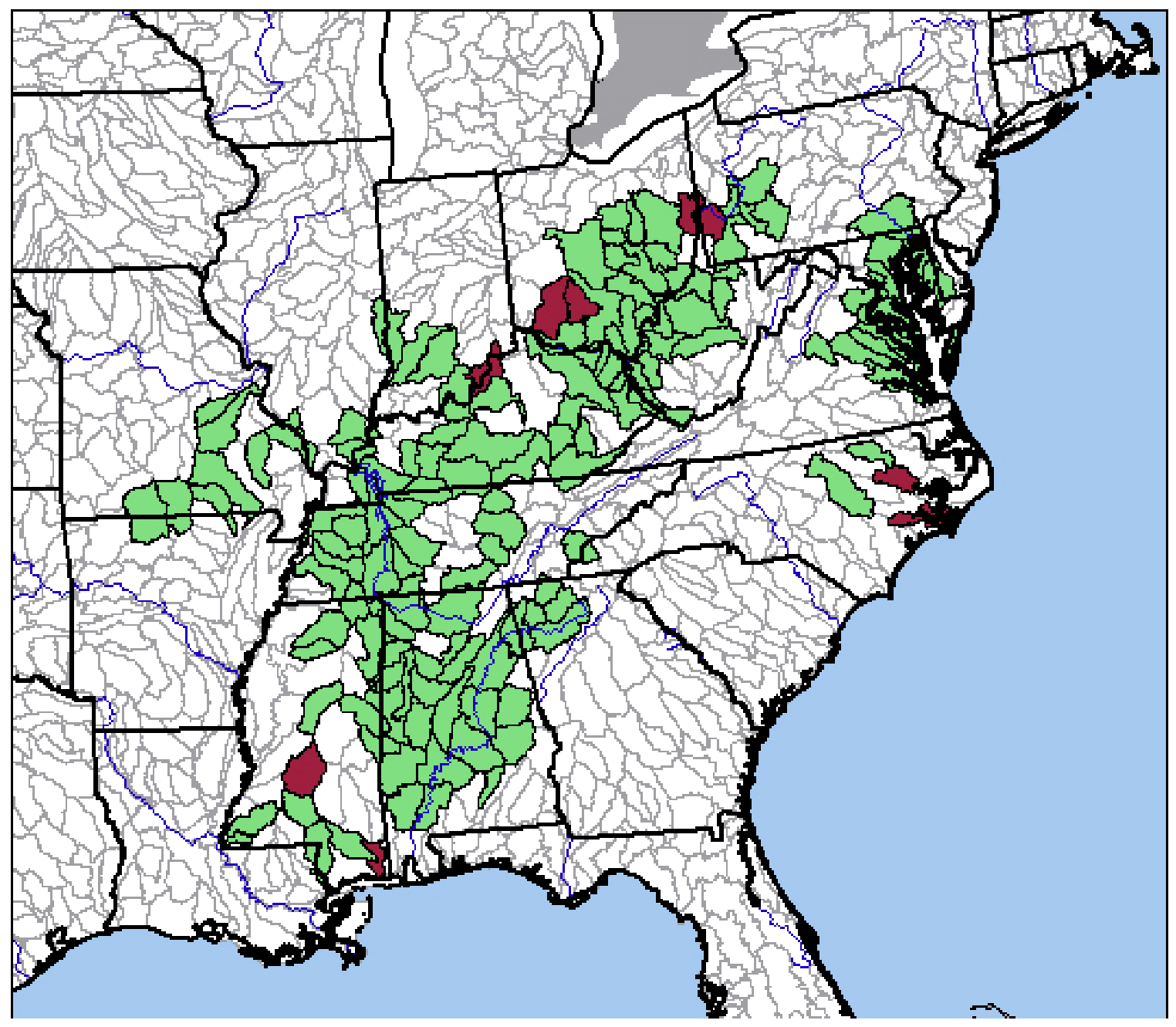

Figure 3. Distribution of the Least Brook Lamprey, Lampetra aepyptera. Green shading represents extant distribution. Maroon shading depicts historic distribution. (Adapted from NatureServe 2005). 


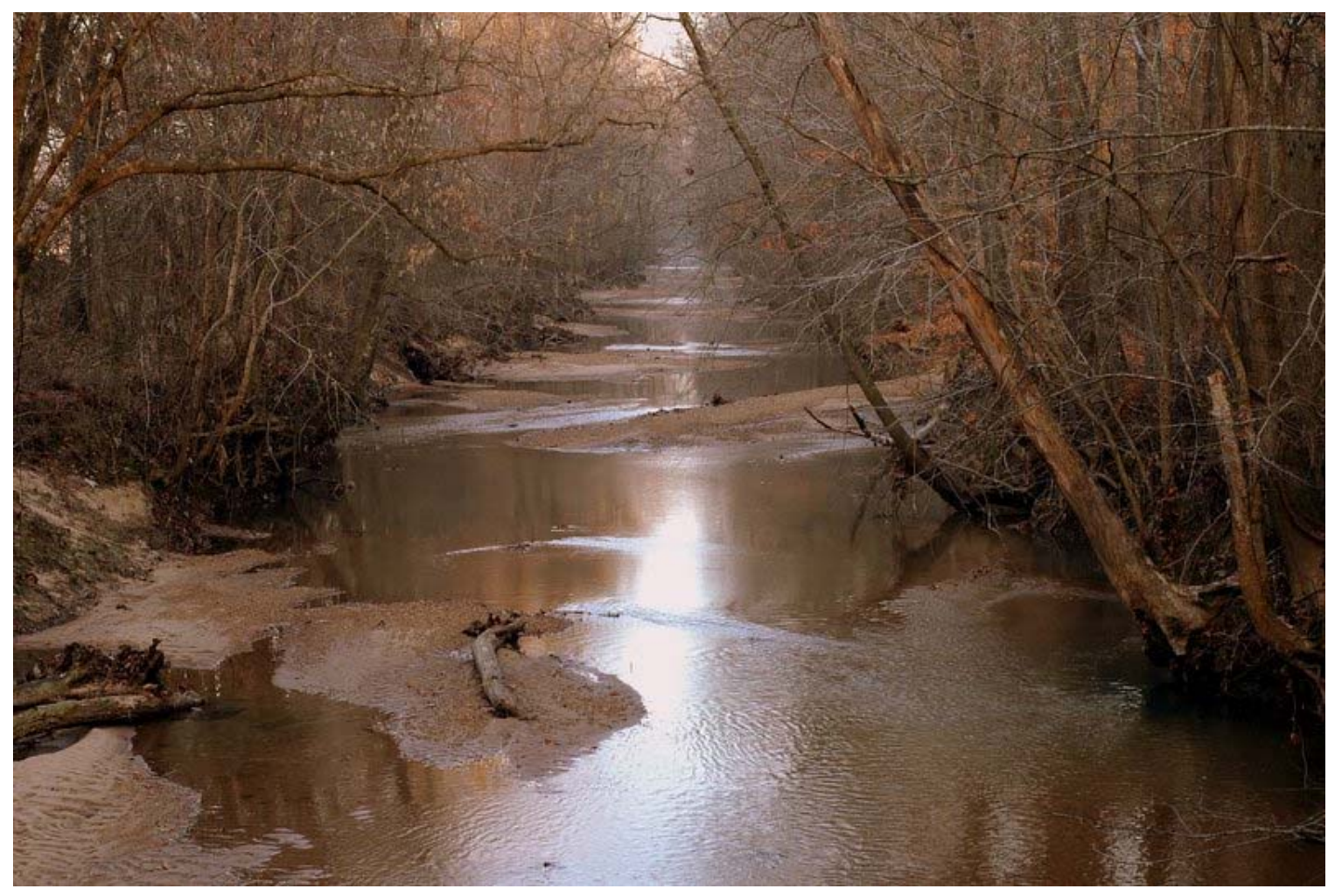

Figure 4. Typical Habitat of the Least Brook Lamprey, Lampetra aepyptera. Terrapin Creek, Graves Co., KY. Photograph by Breck Martin (2004). 


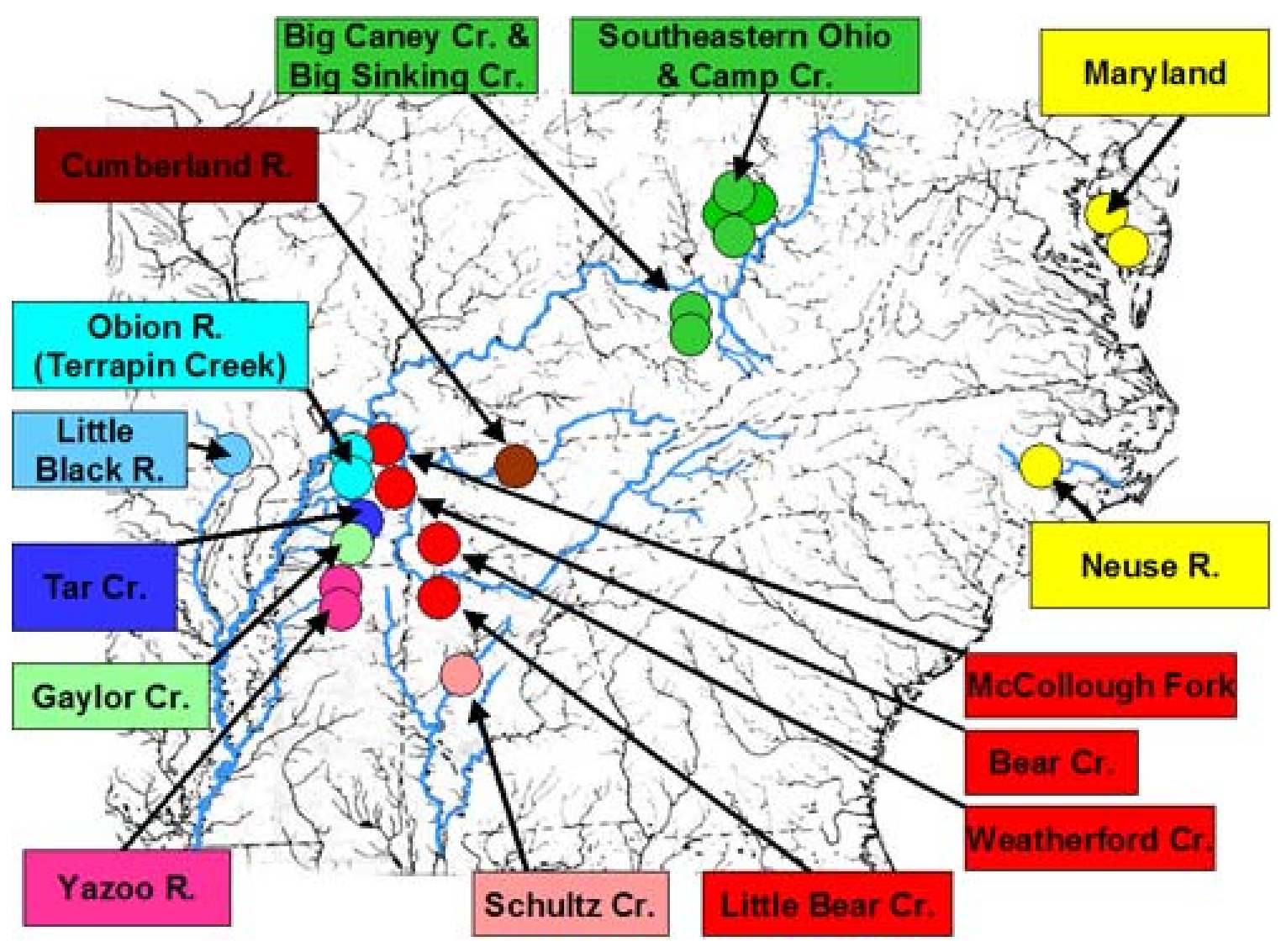

Figure 5. Map of Collecting Localities for Lampetra aepyptera Used in This Study. Colors refer to the major clades identified in this study (Big Caney and Big Sinking Creeks are tributaries of the Little Sandy River). 


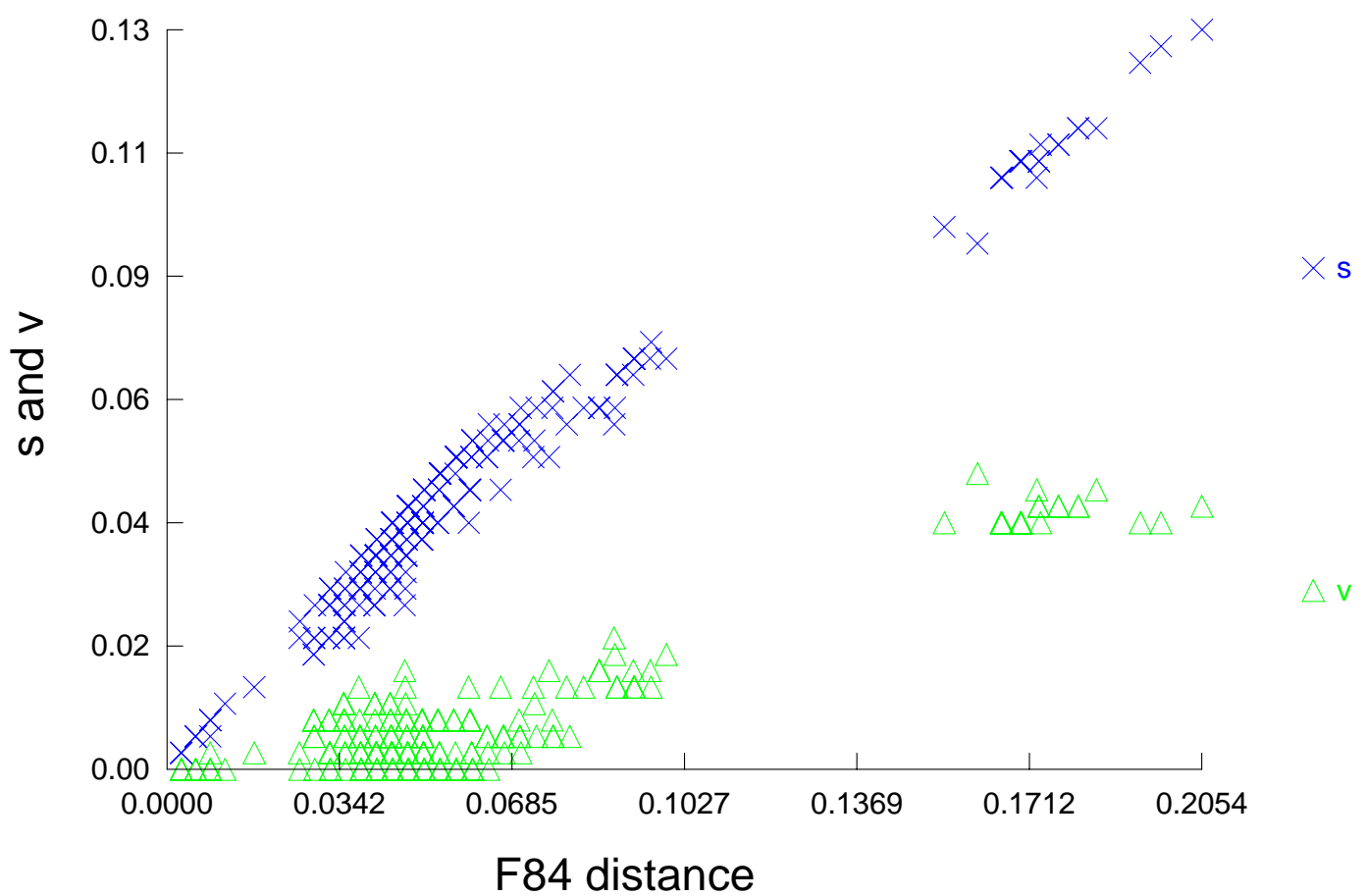

Figure 6. Saturation Plot for the ND3 Data Set. Transitions and transversions are on the $\mathrm{Y}$ axis versus pairwise genetic distance on the $\mathrm{X}$ axis. Blue $\mathrm{Xs}$ represent transitions. Green triangles represent transversions. 


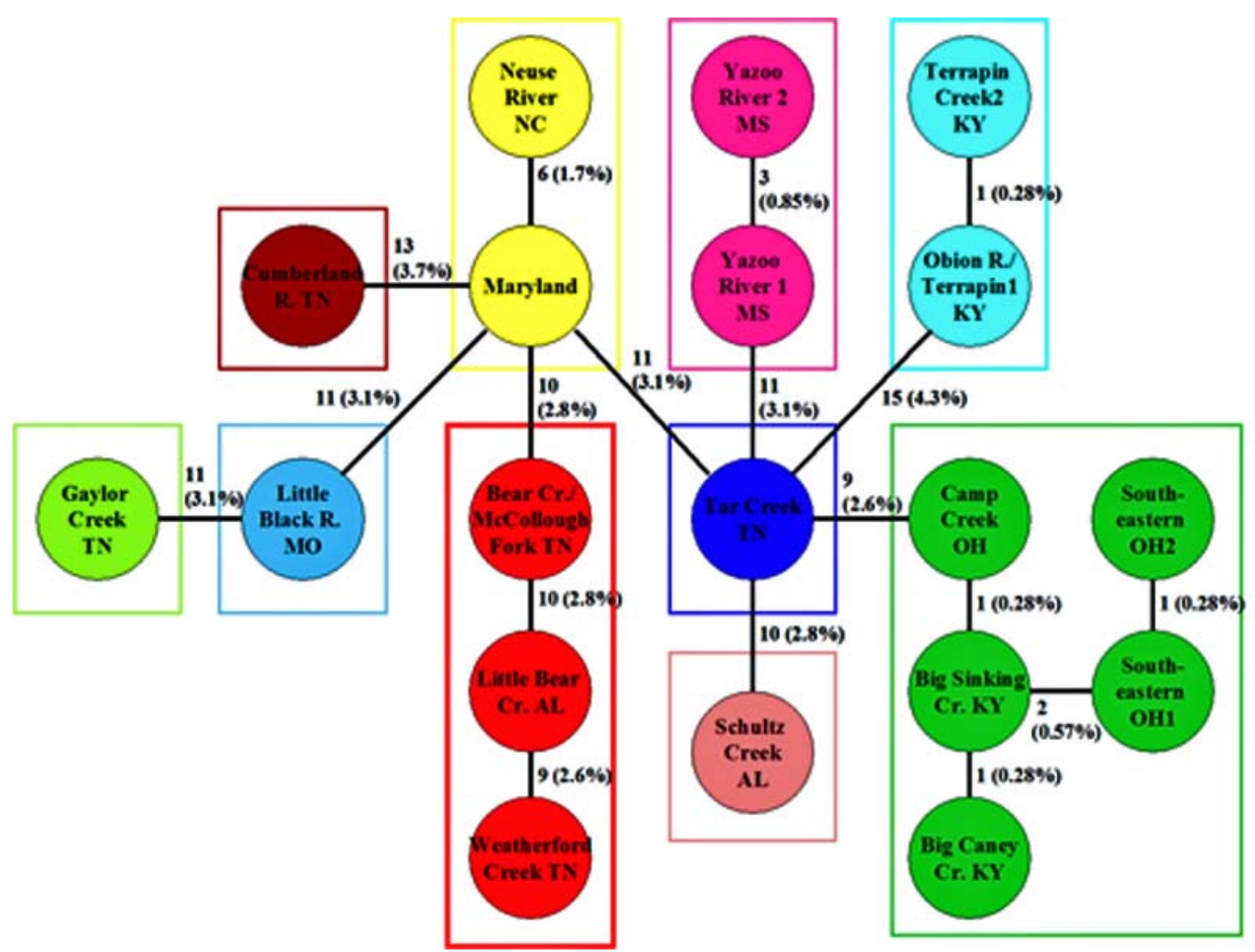

Figure 7. Minimum-spanning Network for the ND3 Data Set. Circles represent unique haplotypes. Squares represent the major clades determined in this study.

Colors refer to collecting localities and major clades. Alternative connections are not presented. 


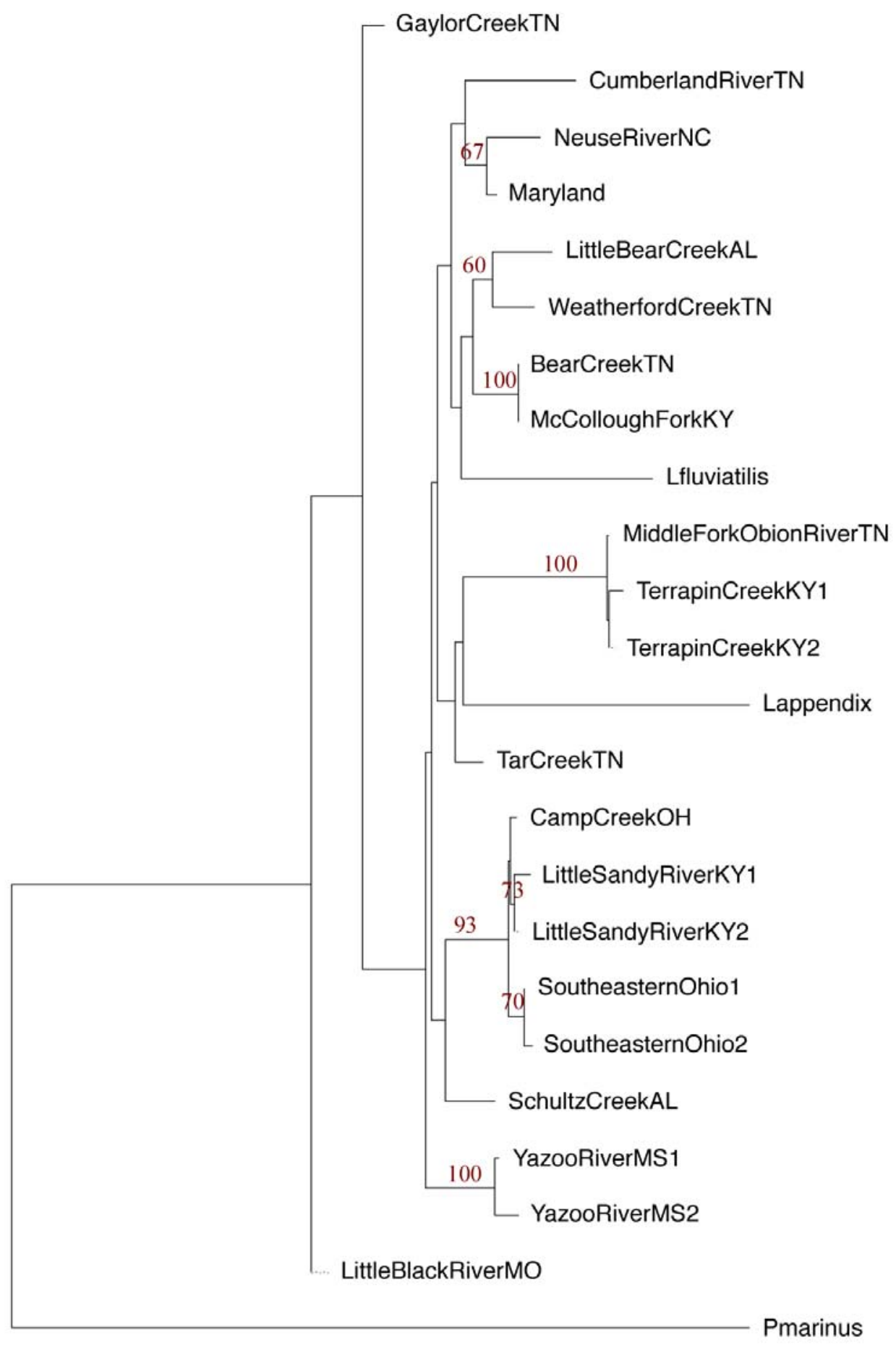

Figure 8. Neighbor-joining Tree Derived from the ND3 Sequence Data. The model of evolution used was GTR $+\mathrm{G}$ (gamma shape $=0.2171$ ). Numbers next to nodes represent bootstrap support (1000 pseudoreplicates). 


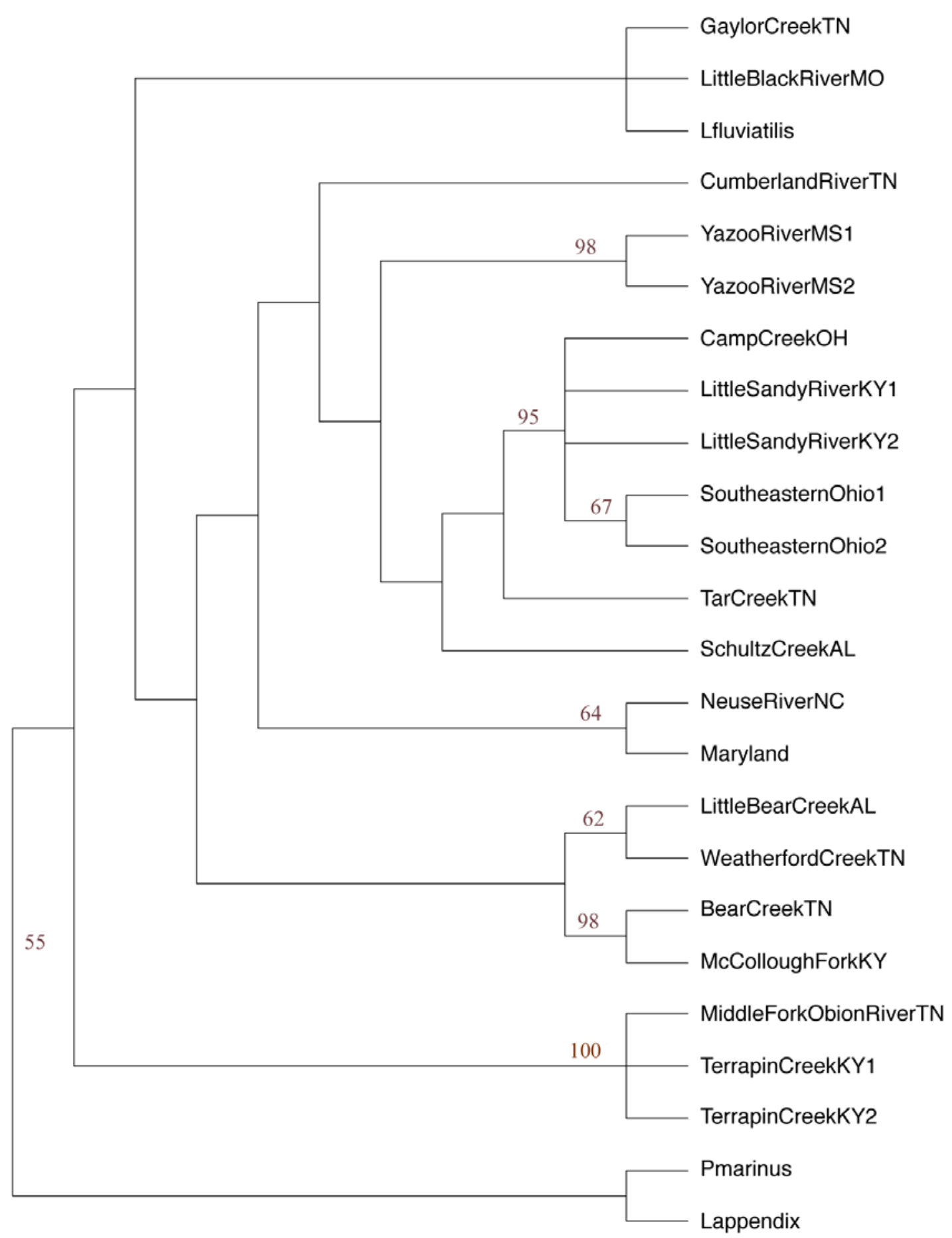

Figure 9. Maximum Parsimony Tree Derived from the ND3 Sequence Data. A strict consensus tree of 6 most parsimonious trees is presented. Numbers at nodes represent bootstrap support (1000 pseudoreplicates). 


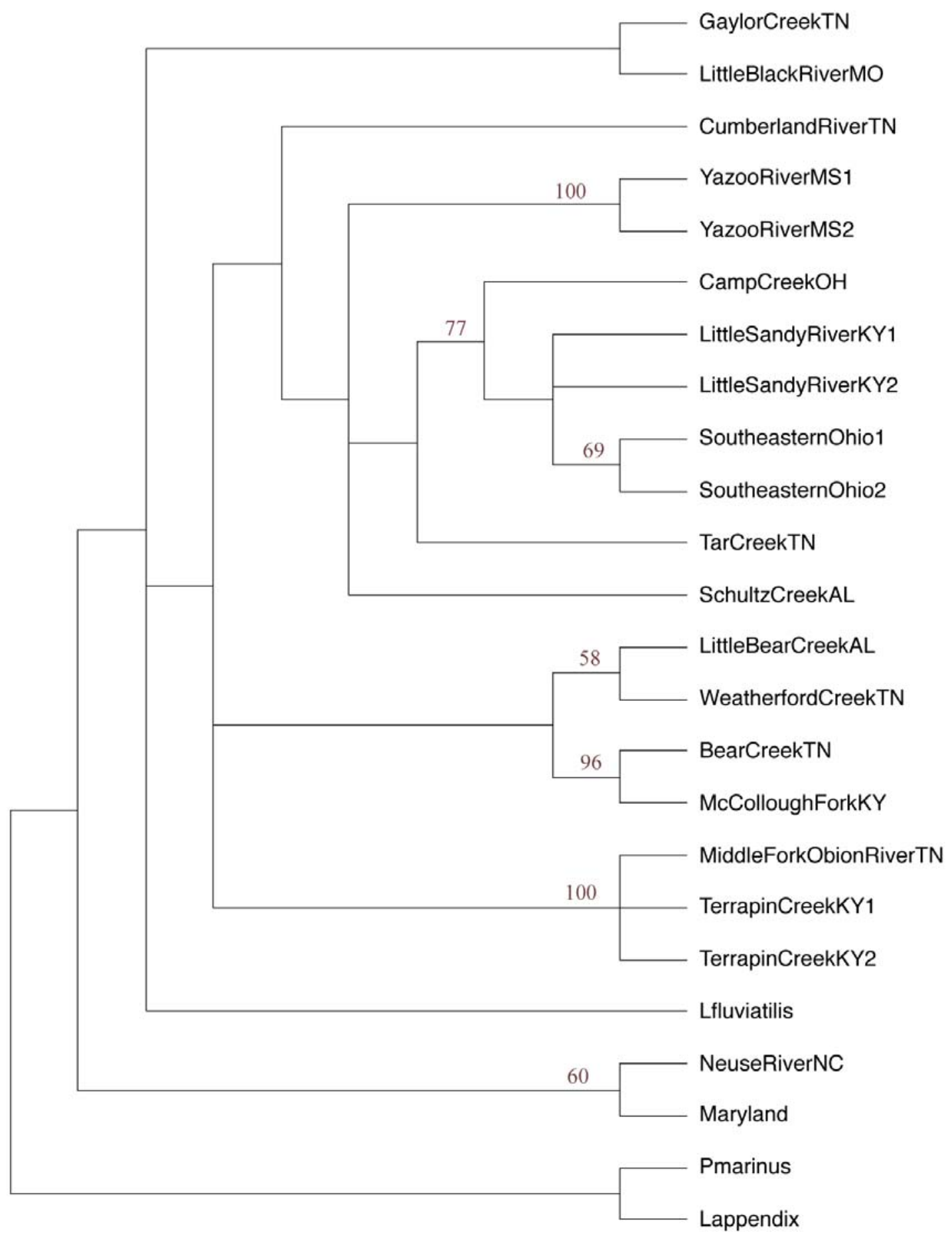

Figure 10. Maximum Likelihood Tree Derived from the ND3 Sequence Data. The GTR + G model (gamma shape $=0.2171$ ) of evolution was used that produced 2 trees with a likelihood score of $-\ln L=989.0$. A strict consensus tree is reported. Numbers represent bootstrap values (100 pseudoreplicates). 


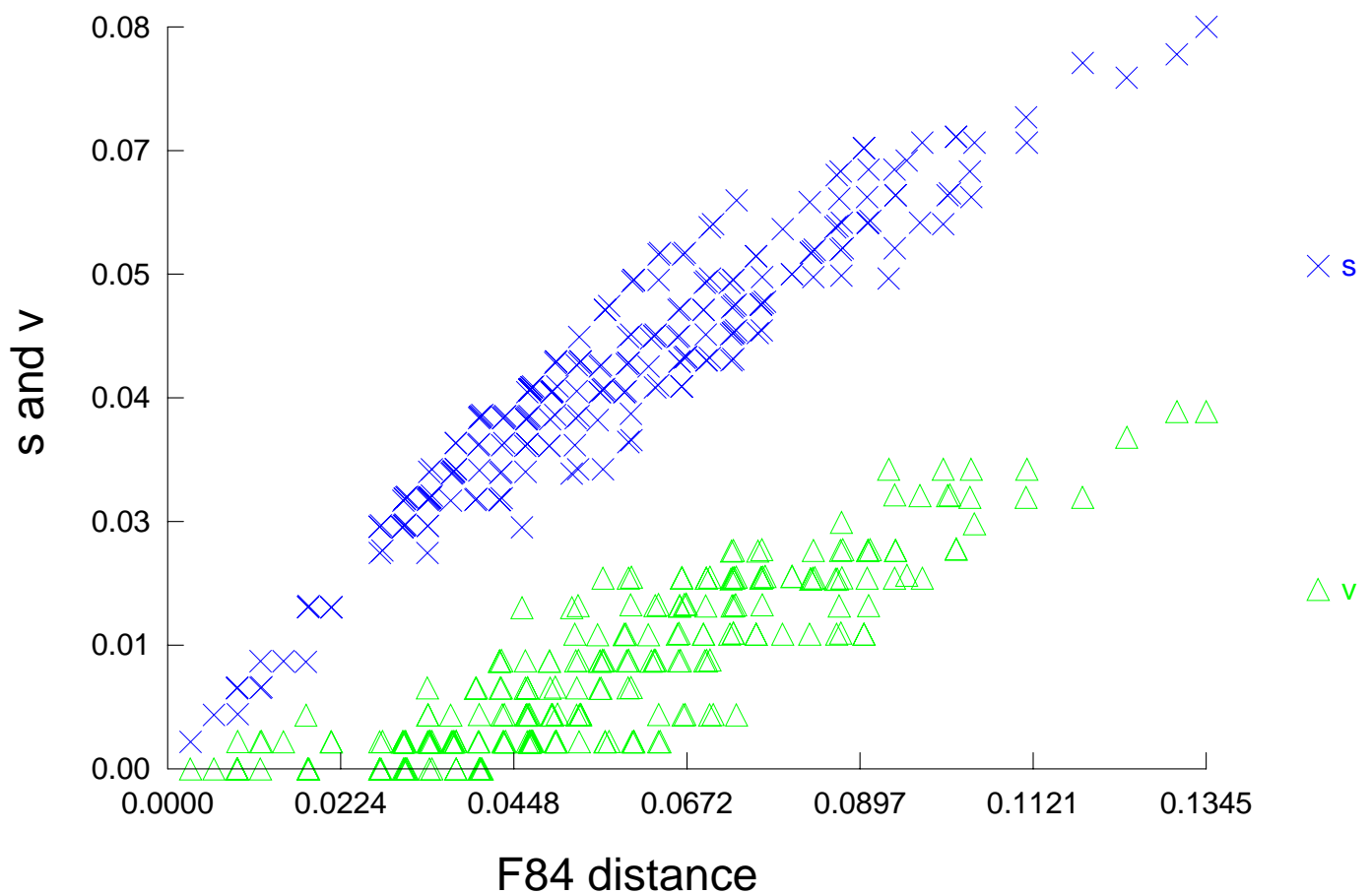

Figure 11. Saturation Plot for the Control Region Data Set. Transitions and transversions are on the $\mathrm{Y}$ axis versus pairwise genetic distance on the $\mathrm{X}$ axis. Blue $\mathrm{Xs}$ represent transitions. Green triangles represent transversions. 


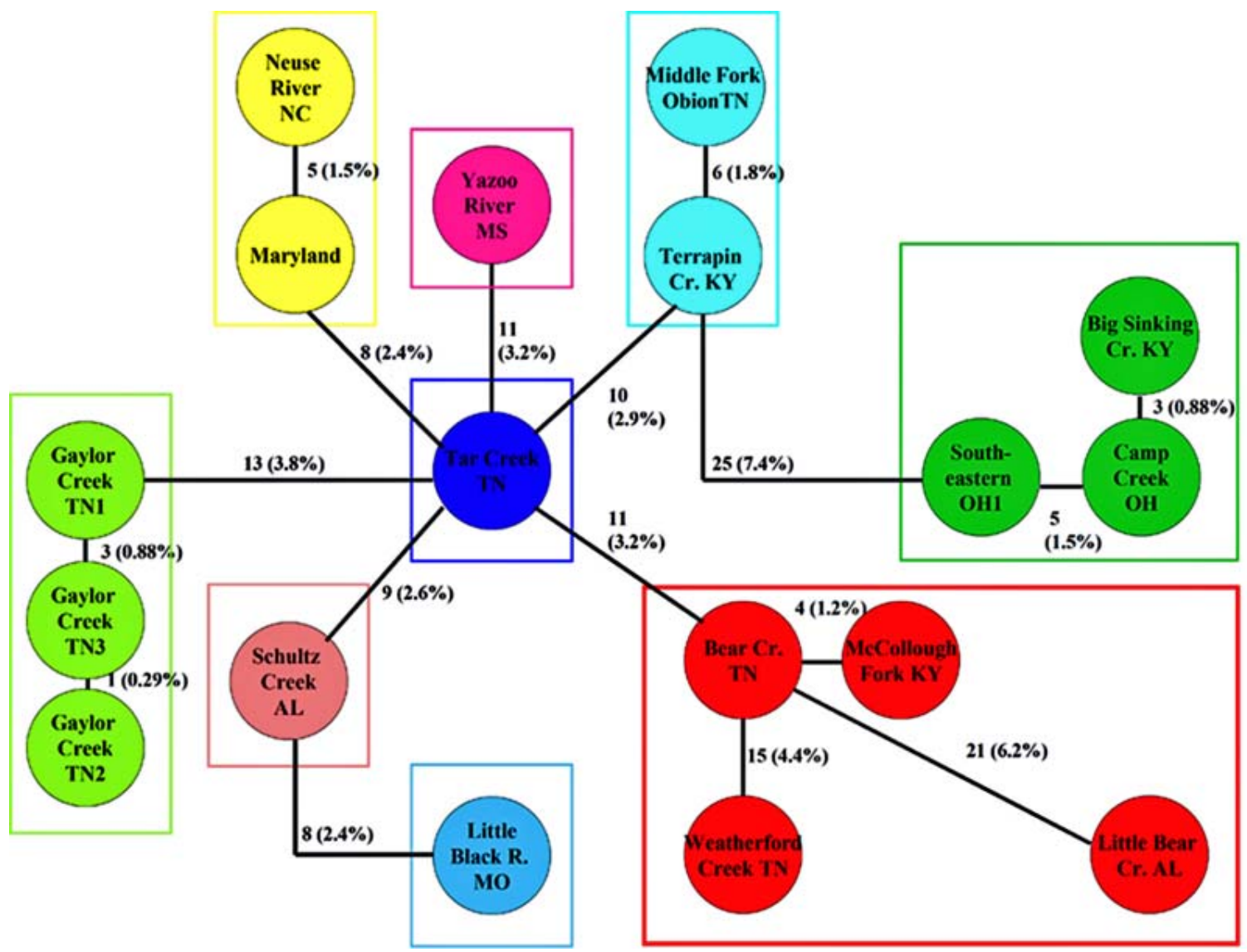

Figure 12. Minimum-spanning Network for the Control Region Data Set. Circles represent unique haplotypes. Squares represent the major clades determined in this study. Colors refer to collecting localities and major clades. Alternative connections are not presented. 


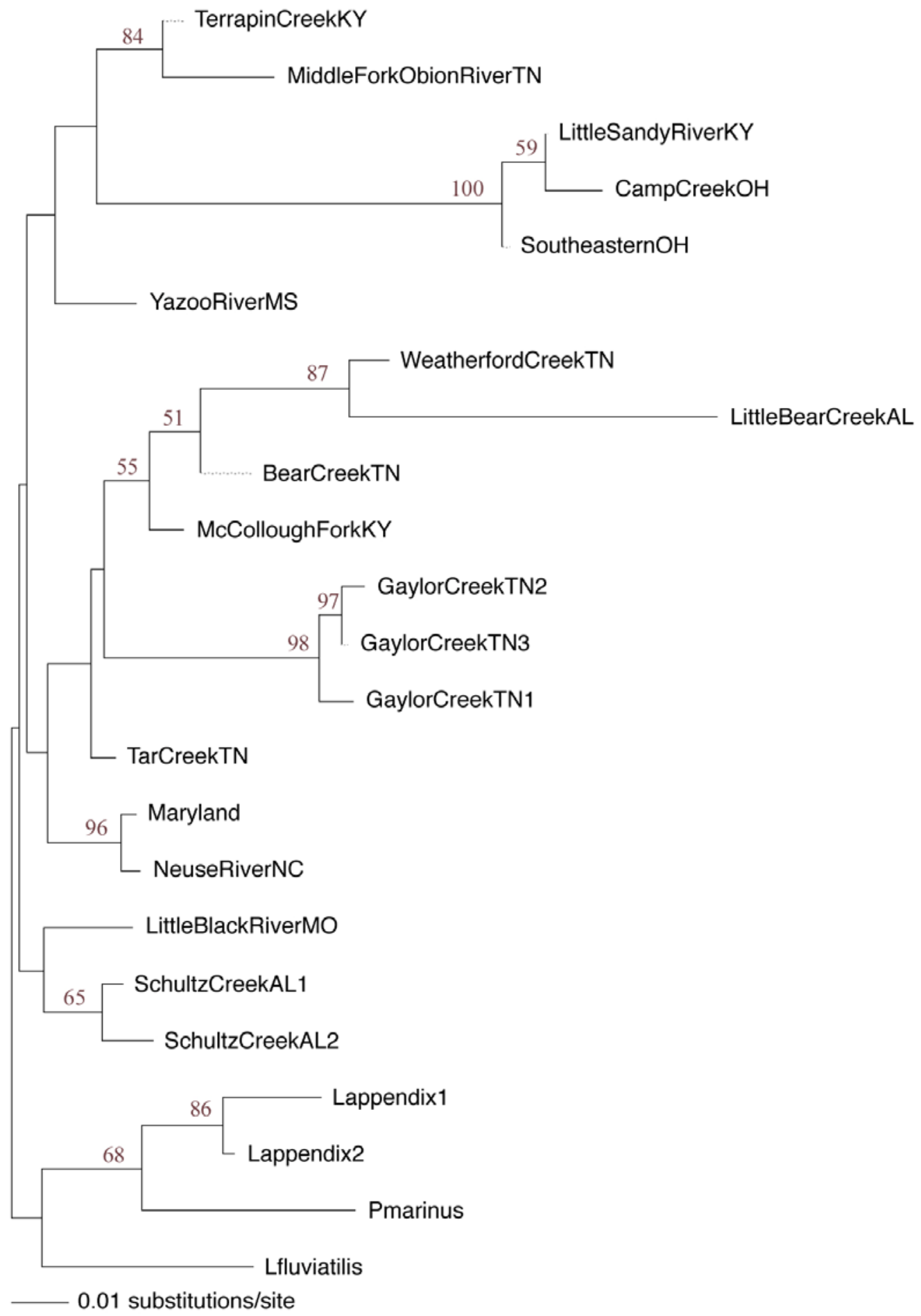

Figure 13. Neighbor-joining Tree Derived from the Control Region Sequence Data. The model of evolution used was GTR $+\mathrm{G}$ (gamma shape=0.1720). Numbers next to nodes represent bootstrap support (1000 pseudoreplicates). 


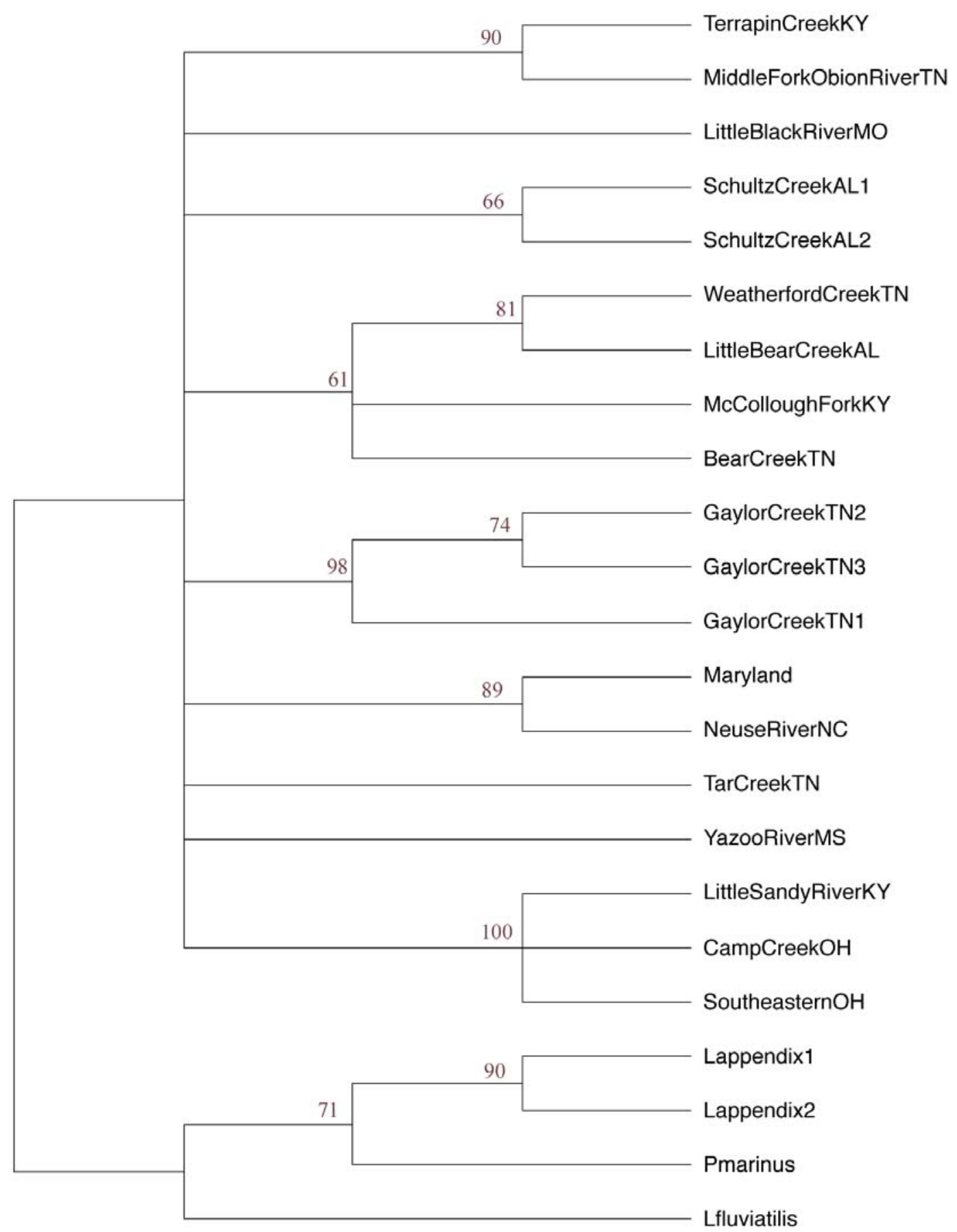

Figure 14. Maximum Parsimony Tree Derived from the Control Region Sequence Data. A strict consensus tree of 105 most parsimonious trees is presented. Numbers at nodes represent bootstrap support (1000 pseudoreplicates). In the bootstrap consensus tree (not shown), the Little Sandy River and Camp Creek represent a node supported by a bootstrap value of 64 . 


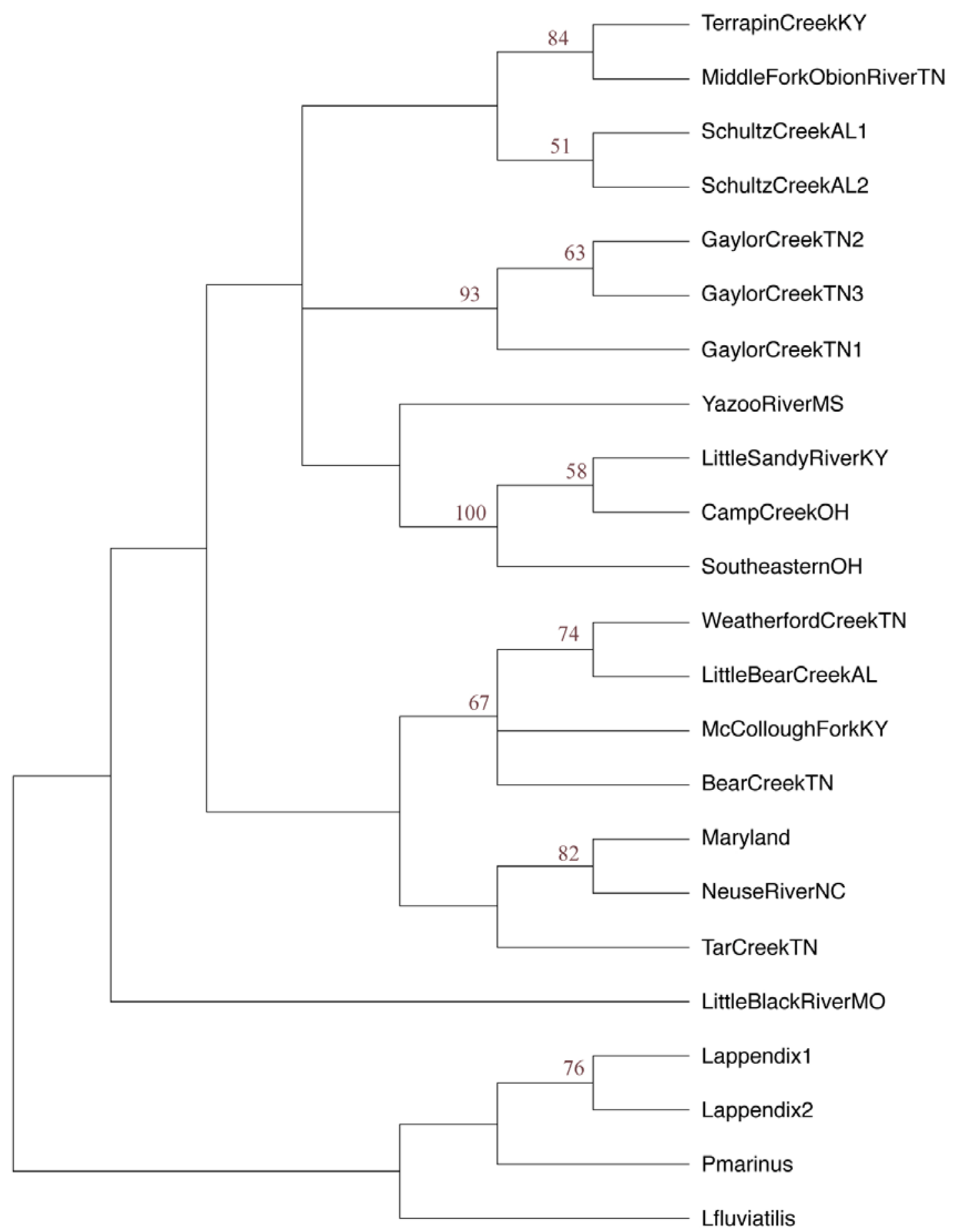

Figure 15. Maximum Likelihood Tree Derived from the Control Region Sequence Data. The GTR + G model (gamma shape $=0.1720$ ) of evolution was used that produced 1 tree. The log likelihood score could not be determined due to missing data. Numbers represent bootstrap values (100 pseudoreplicates). 


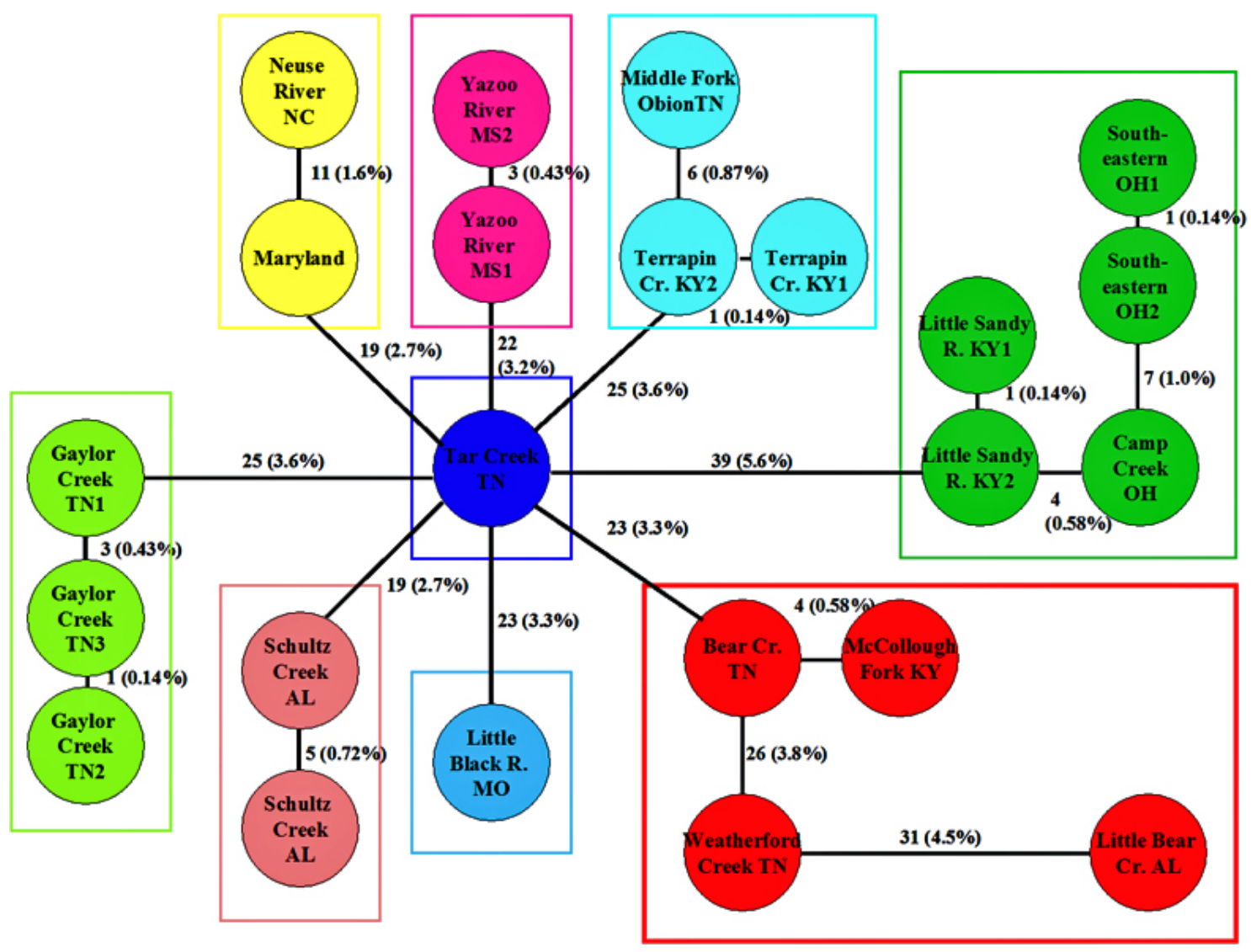

Figure 16. Minimum-spanning Network for the ND3/control Region Data Set. Circles represent unique haplotypes. Squares represent the major clades determined in this study. Colors refer to collecting localities and major clades. Alternative connections are not presented. 


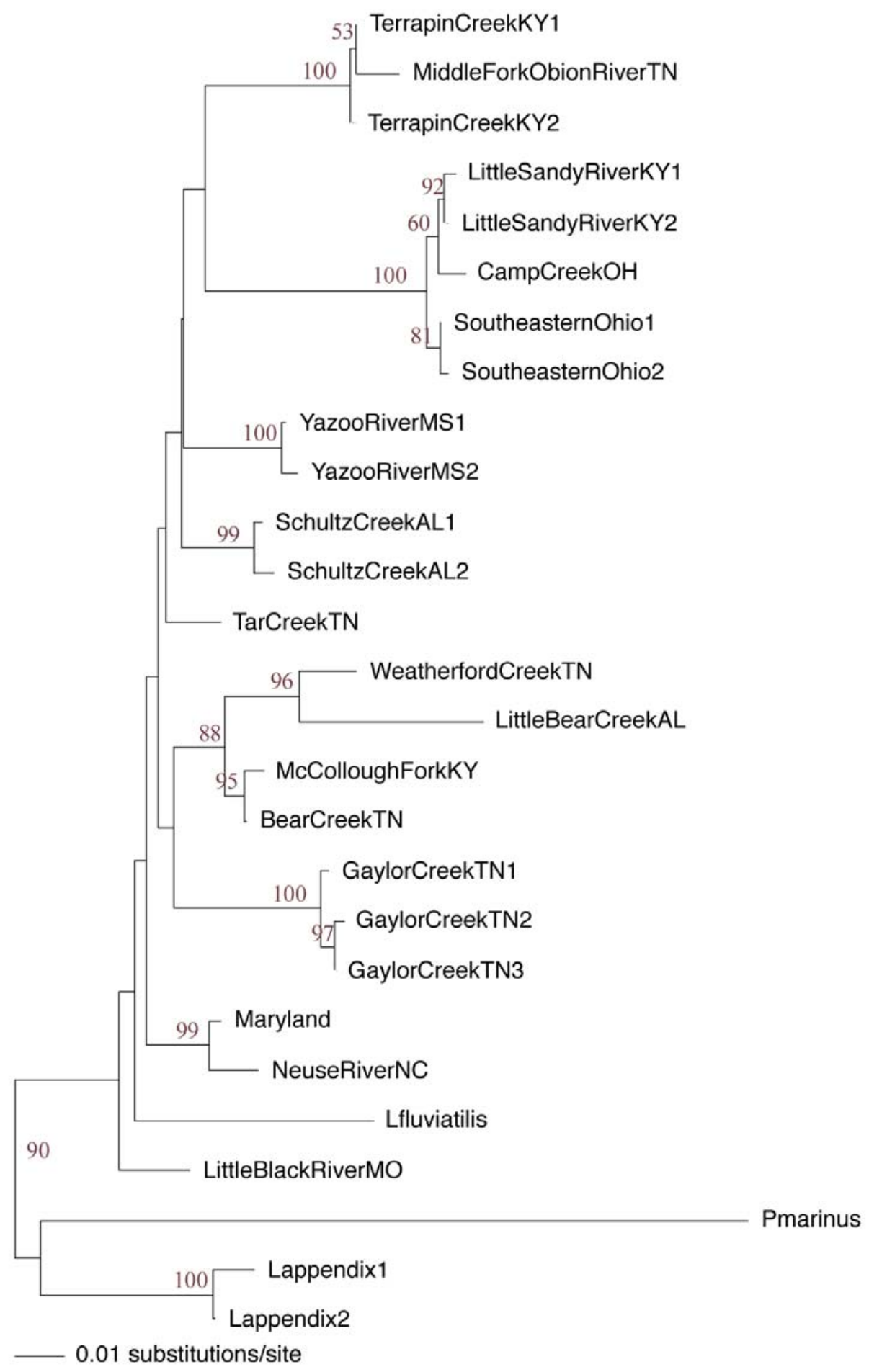

Figure 17. Neighbor-joining Tree Derived from the ND3/control Region Sequence Data. The model of evolution used was GTR $+\mathrm{G}$ (gamma shape=0.2030). Numbers next to nodes represent bootstrap support (1000 pseudoreplicates). 


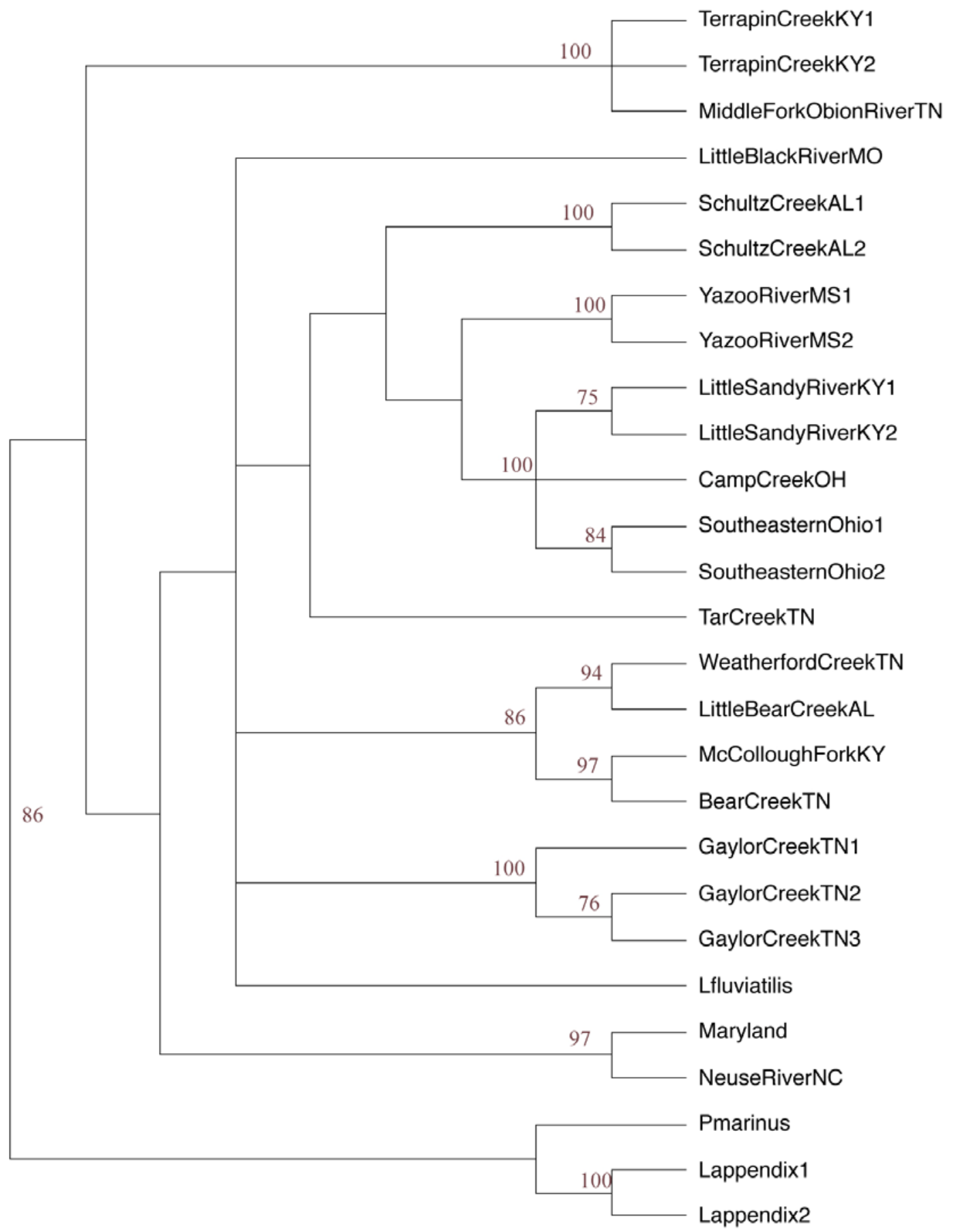

Figure 18. Maximum Parsimony Tree Derived from the ND3/control Region Sequence Data. A strict consensus tree of 6 most parsimonious trees is presented. Numbers at nodes represent bootstrap support (1000 pseudoreplicates). In the bootstrap consensus tree (not shown), the Little Sandy River and Camp Creek represent a node supported by a bootstrap value of 55 . 


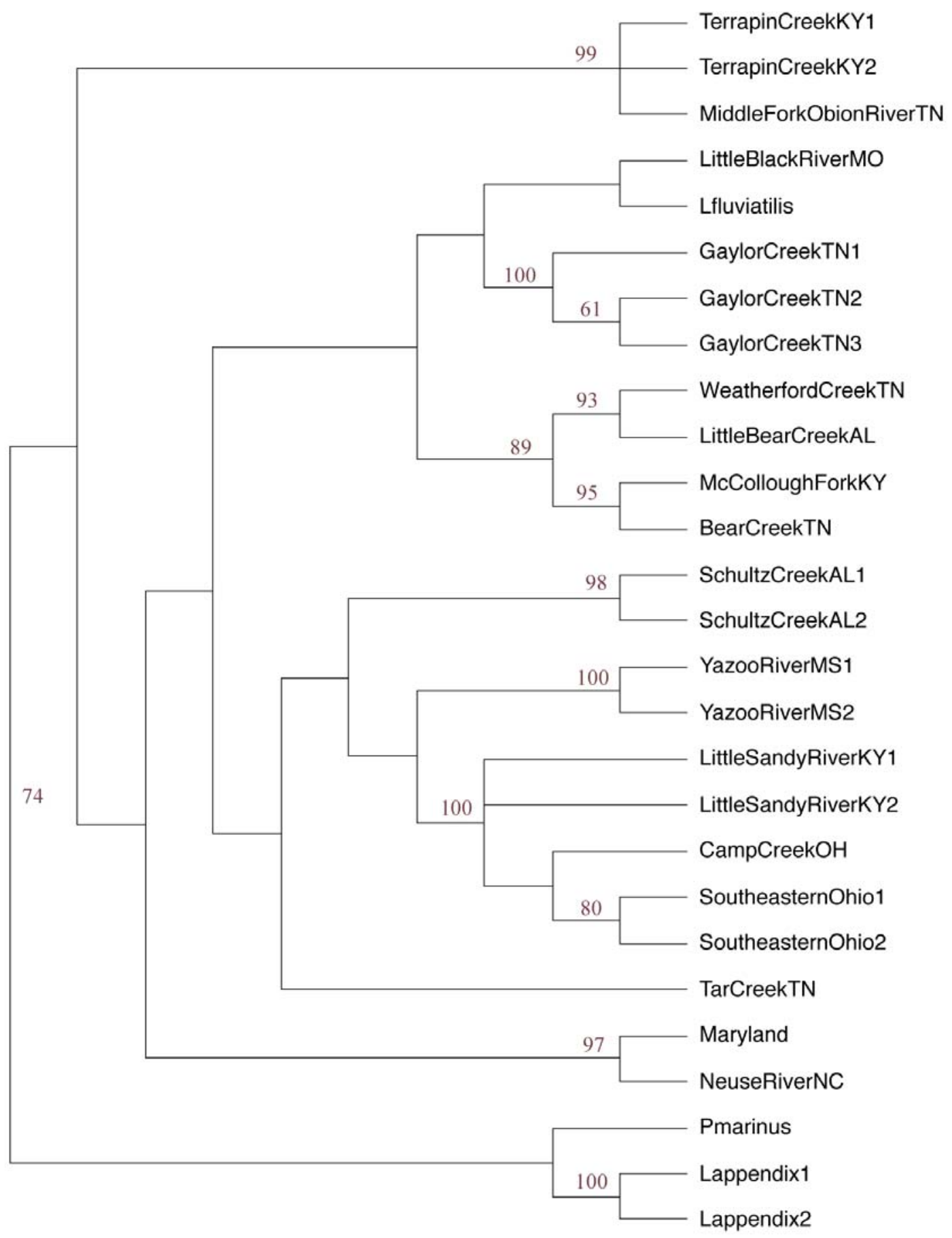

Figure 19. Maximum Likelihood Tree Derived from the ND3/control Region Sequence Data. The GTR + G model (gamma shape $=0.2030$ ) of evolution was used that produced 1 tree. The log likelihood score could not be determined due to missing data. Numbers represent bootstrap values (100 pseudoreplicates). 


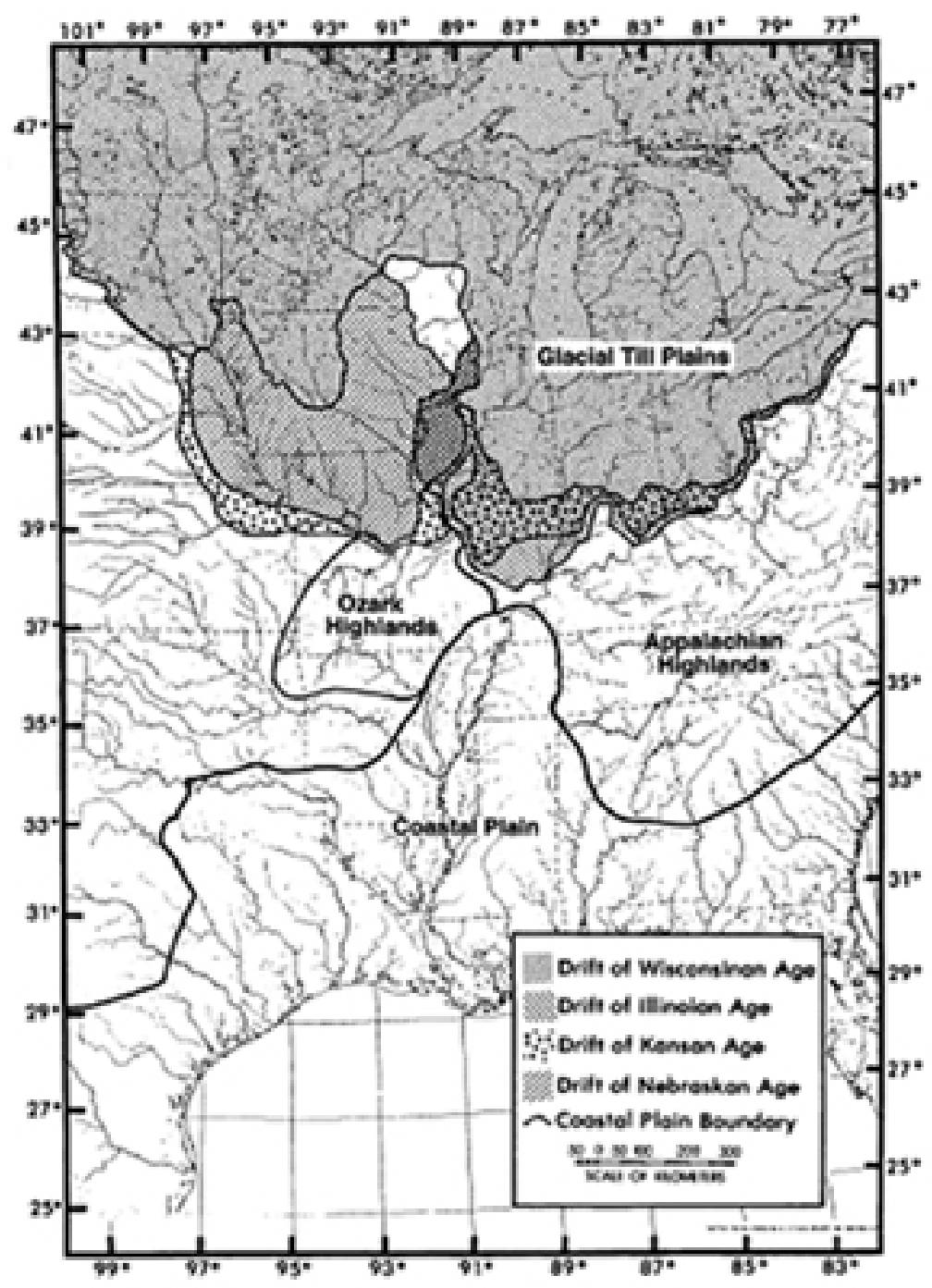

Figure 20. Map Depicting the Mississippi Embayment. The Mississippi Embayment represents the extent of sea level incursions into the United States, and surrounding physiographic provinces (Adapted from Strange and Burr 1997). 


\section{Appendix 1}

Appendix 1. Collecting Locations and Collectors.

\begin{tabular}{|c|c|c|c|c|}
\hline Sample Location & Drainage & County & State & Collector \\
\hline Strouds Run & Hocking-Ohio & Athens & $\mathrm{OH}$ & A. Drake \\
\hline Shade River & Hocking-Ohio & Athens & $\mathrm{OH}$ & A. Drake \\
\hline Indian Run & Hocking-Ohio & Hocking & $\mathrm{OH}$ & A. Drake \\
\hline Gaylor Creek & Hatchie-Mississippi & Hardeman & TN & A. Drake \\
\hline Little Black River & Black-White & Ripley & MO & A. Drake \\
\hline Davis Mill Creek & Marshyhope-Nanticoke & Dorchester & MD & A. Drake \\
\hline Burnt Mill Creek & Wicomico & Wicomico & MD & A. Drake \\
\hline Terrapin Creek & Obion-Mississippi & Graves & KY & $\begin{array}{l}\text { A. Drake, } \\
\text { H. Martin }\end{array}$ \\
\hline Middle Fork Obion & Mississippi & Henry & $\mathrm{TN}$ & H. Martin \\
\hline Big Sinking Creek & Little Sandy River-Ohio & Carter & KY & A. Drake \\
\hline Big Caney Creek & Little Sandy River-Ohio & Elliott & KY & D. Eisenhour \\
\hline Tar Creek & Forked Deer-Mississippi & McNairy & TN & A. Drake \\
\hline Schultz Creek & Cahaba-Alabama & Bibb & $\mathrm{AL}$ & A. Drake \\
\hline Yellow Leaf Creek & $\begin{array}{c}\text { Yocona-Talahatchie- } \\
\text { Yazoo }\end{array}$ & Lafayette & MS & S. Adams \\
\hline Kettle Creek & $\begin{array}{c}\text { Yocona-Talahatchie- } \\
\text { Yazoo }\end{array}$ & Lafayette & MS & S. Adams \\
\hline Bear Creek & Big Sandy-Tennessee & Henry & $\mathrm{TN}$ & H. Martin \\
\hline McCollough Fork & Blood-Tennessee & Calloway & KY & H. Martin \\
\hline Weatherford Creek & Indian Creek-Tennessee & Wayne & TN & R. Mayden \\
\hline Neuse River & Atlantic & Johnston & $\mathrm{NC}$ & $\begin{array}{l}\text { J. Reynolds, } \\
\text { C. Reynolds }\end{array}$ \\
\hline Little Bear Creek & Tennessee & Franklin & $\mathrm{AL}$ & R. Mayden \\
\hline Camp Creek & Scioto-Ohio & Pike & $\mathrm{OH}$ & \\
\hline
\end{tabular}




\section{Appendix 2}

Appendix 2. Genbank Accession Numbers for Outgroup Sequences. *(Lampetra appendix1 refers to a haplotype identified from Zekiah Swamp Run-Potomac River and Big Sycamore Creek-Clinch River; L. appendix2 represents an additional haplotype detected from Big Sycamore Creek-Clinch River. L. appendix samples were provided by R. Mayden).

\begin{tabular}{|c|c|c|}
\hline Species & Accession \#s-ND3 & Accession \#s-CR \\
\hline Lampetra fluviatilis & NC001131 & NC001131 \\
\hline Lampetra appendix & AF177975 & N/A \\
\hline Lampetra appendix ${ }^{*}$ & Will be submitted & Will be submitted \\
\hline Lampetra appendix ${ }^{*}$ & Will be submitted & Will be submitted \\
\hline Petromyzon marinus & NC001626 & NC001626 \\
\hline
\end{tabular}

